\title{
النوازل العقدية للمسلمين الجدد
}

\author{
زياد بن حمد العامر \\ الأستاذ المشارك في العقيدة والمذاهب الفكرية المعاصرة- جامعة المجمعة- المملكة العربية السعودية
}

Zha1430@gmail.com

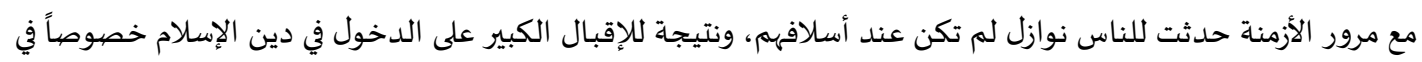

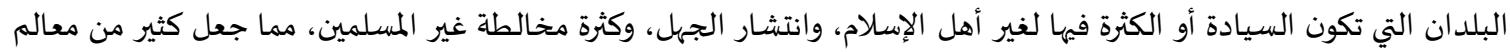

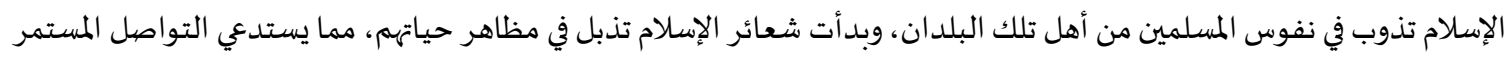

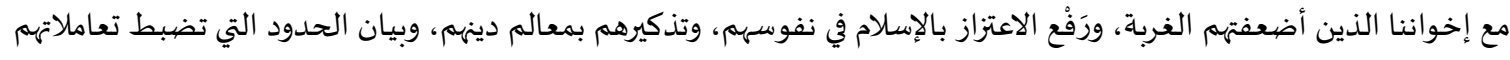

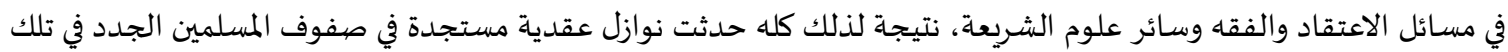

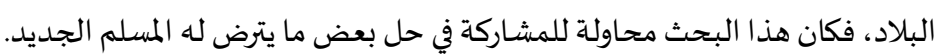

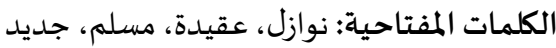
(c) (1)

الحمد الله رب العالمين، والصهلاة والسلام على نبينا محمد، وعلى آله وأصحابه أجمعين ، أما بعد :

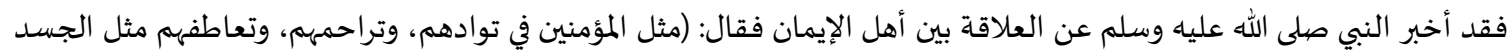

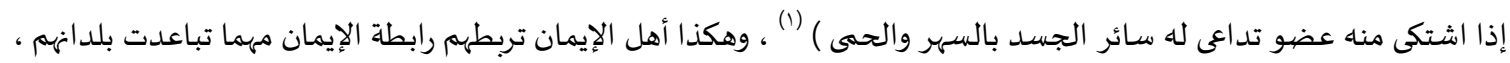

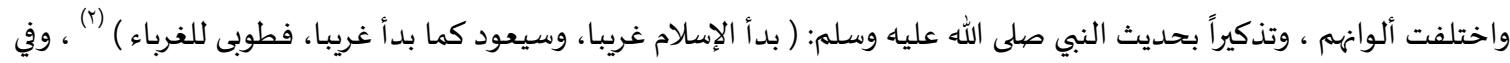

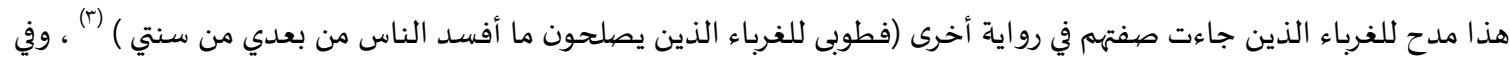

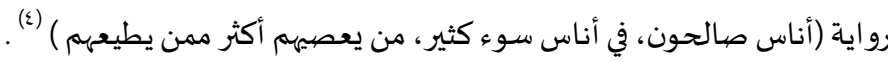

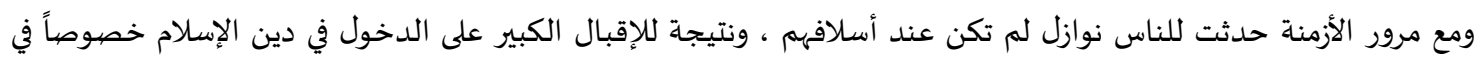

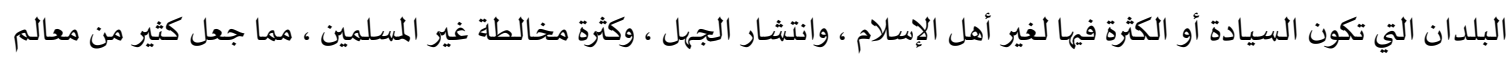

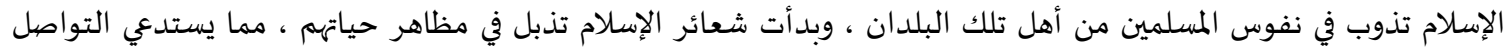

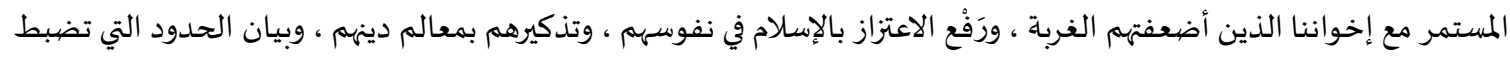

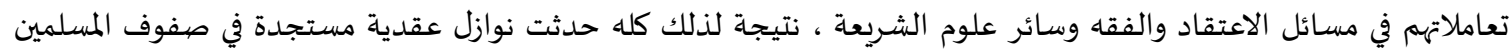

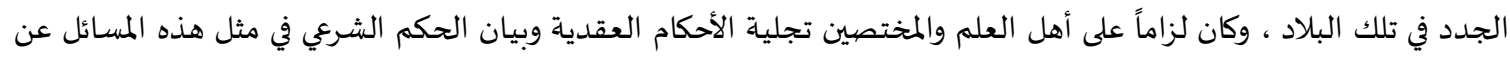

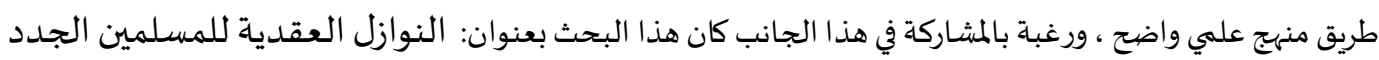

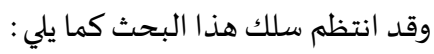
المقدمة : وفهها مدخل للتعريف بالبحث ، وخطة البحث ، وهدف البحث ، والدراسات السابقة . التمهيد : في تعريف مفردات عنوان البحث .

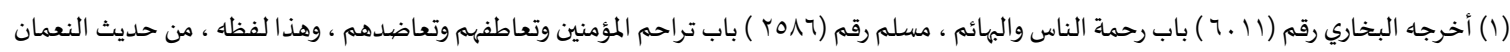

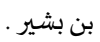

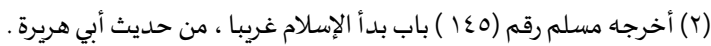

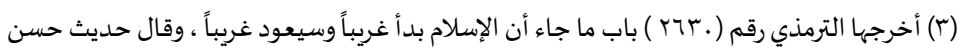

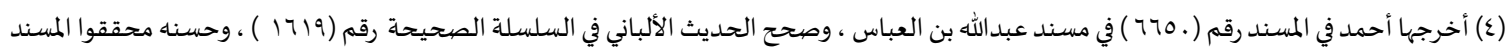
لوجود ابن لهيعة في الإسناد. 
المبحث الأول : وفيه بيان أهمية العناية بدراسـة النوازل العقدية المتعلقة بالمسلمين الجدد.

المبحث الثاني : وفيه بيان جملة من القواعد الشرعية المؤثرة في النوازل العقدية للمسلمين الجدد .

المبحث الثالث : منهجية التعامل المرحلي مع من عرف طريقه إلى الإسلام من خلال أصحاب الانحرافات العقدية أو الفكرية

الخطيرة .

المبحث الرابع : النوازل المتعلقة بنطق الشهادتين.

المبحث الخامس : النوازل المتعلقة بالدخول الكامل أو الجزئي للإسلام .

المبحث السادس : النوازل المتعلقة بالموقف من المجتمع الجديد بعد الإسلام .

الخاتمة : وفيها أبرز النتائج ، وأهم التوصيات .

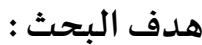

يمكن إجمال هدف البحث في بيان الموقف الشرعي في النوازل العقدية المتعلقة بالمسلمين الجدد.

منهج البحث :

يتصف هذا البحث بالمنهج الاستقرائي والتحليلي ، حيث يتم جمع المادة العلمية الأساسية للبحث واستقرائها ثم تحليل تلك

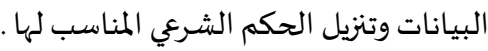

الدراسـات السـابقة :

لم أقف على دراسات خاصةة تتعلق بالنوازل العقدية المتعلقة بالمسلمين الجدد .

أسأل الله فياه التوفيق والسداد، وأن يكون إضـافة علمية في الدراسـات الشرعية .

التمهيد : في تعريف مفردات عنوان البحث .

أولاً : التعريف الإفرادي لألفاظ عنوان البحث :

$$
\text { •. التعريف بالنوازل }
$$

قال ابن فارس : ( النون والزاء واللام كلمة صحيحة تدل على هبوط شيء ووقوعاه. ونزل عن دابته نزولا. ونزل المطر من السماء نزولا.

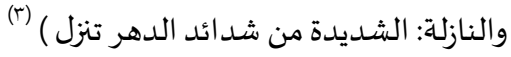
النوازل في الاصطلاح:

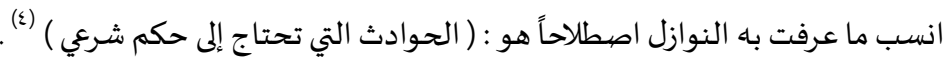

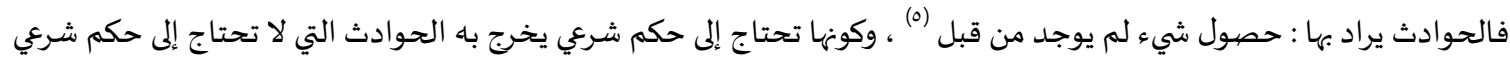
مثل بعض الحوادث اللغوية والطبية ومثل بعض الحوادث الكونية كالكوارث والبراكين.

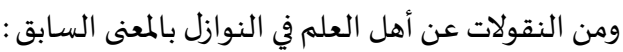

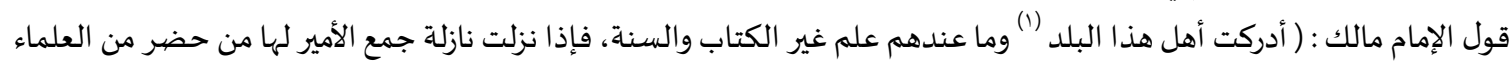
فما اتفقوا علياء أنفذه ) (r)

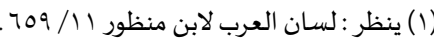

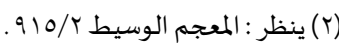

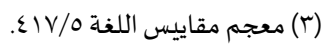

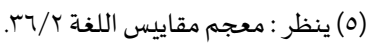


وقول الشافعي : ( فليست تنزل بأحد من أهل دين الله نازلة إلا وفي كتاب الله الدليلُ على سبيل الهدى فهيا ) (م) .

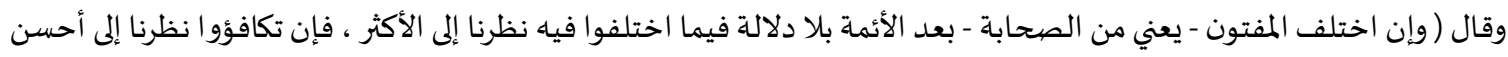

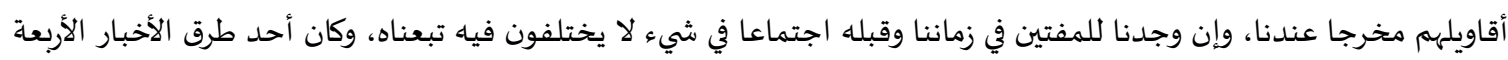

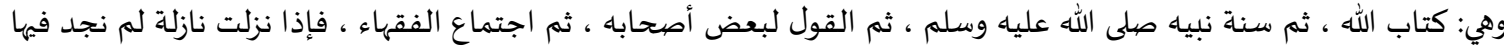

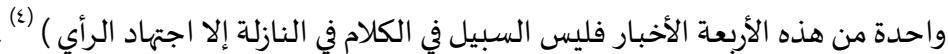

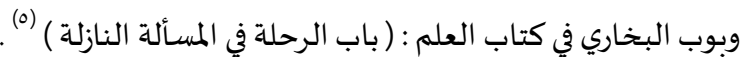

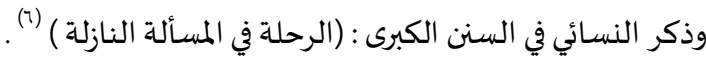

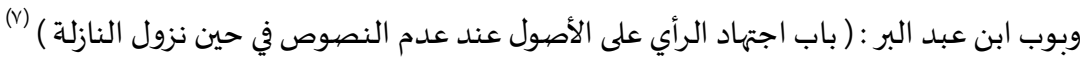

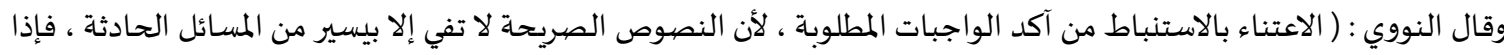

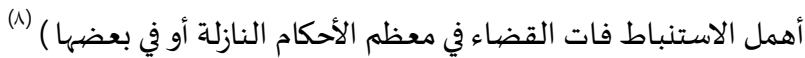

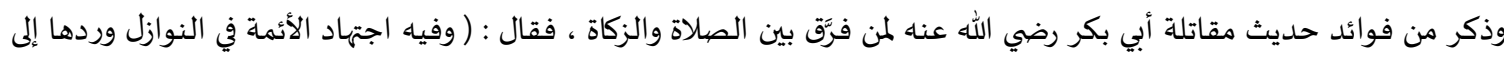

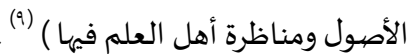
وقال ابن القيم : ( وقد كان أصحاب رسول الله - صلى الله عليه وسلم - يجتهدون في النوازل، ويقيسون بعض الأحكام على بعض،

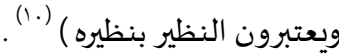
وهناك بعض الألفاظ المشابهة للنوازل مثل (11) • مالوقائع أو الواقعات. مالحوادث. أمسائل المستجدة.

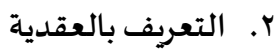
العقدية في اللغة : العقدية والعقيدة بمعنى واحد، والعقيدة اسم فعيلة من عقد ، وهو الشد والربط والجزم . قال ابن فارس: ( العين والقاف والدال أصل واحد يدل على شد وشدة وثوق، وإليه ترجع فروع الباب كلها... وعقد قلبه على كذا فلا

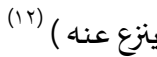
وقال الفيومي: ( اعتقدت كذا : عقدت عليه القلب والضمير، حتى قيل : العقيدة: ما يدين الإنسان بهاه ، وله عقيدة حسنة: سالمة من

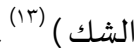

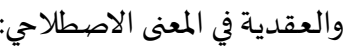

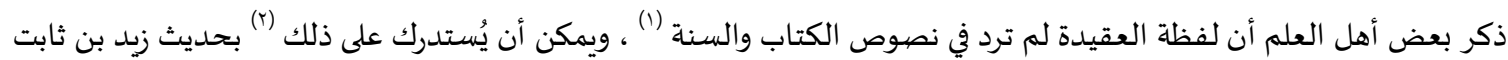

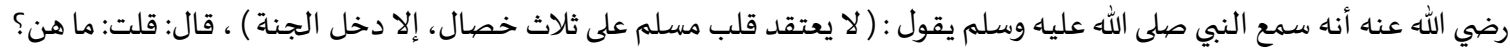

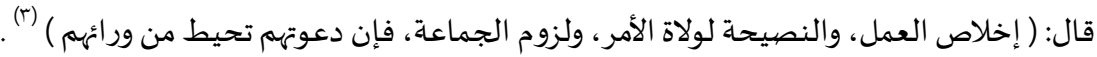

$$
\begin{aligned}
& \text { (1) يعني المدينة النبوية. . }
\end{aligned}
$$

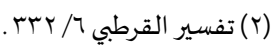

$$
\begin{aligned}
& \text { (Y) الرسالة للشافعي ص (Y) تفسير لقرصبي } 19
\end{aligned}
$$

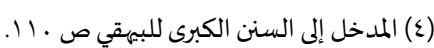

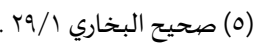

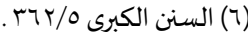

$$
\begin{aligned}
& \text { جامع بيان العلم وفضله / (V) }
\end{aligned}
$$

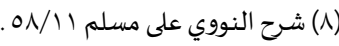

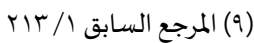

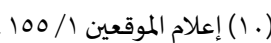

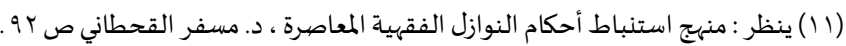

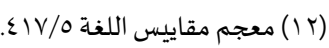

$$
\begin{aligned}
& \text { (T) }
\end{aligned}
$$


والمراد بالعقيدة في هذا البحث العقيدة الإسلامية ، ويمكن تعريفها بأهها ( ما يشد ويربط الإنسان قلبه عليه من أصول الإيمان وما يلحق بها )

وتجدر الإشارة هنا إلى أن الجزم واليقين متوجه إلى أصول الإيمان ، أما بعض المسائل الاحتمالية غير القطعية مما يُلحق بأصهول

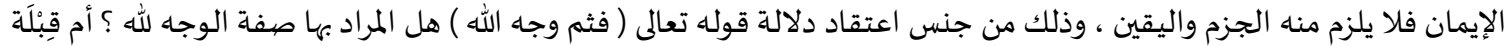

قال ابن تيمية : الدين نوعان: أمور خبرية اعتقادية ، وأمور طلبية عملية.

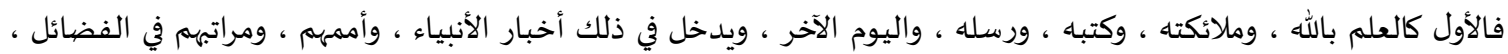

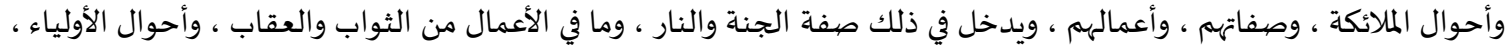

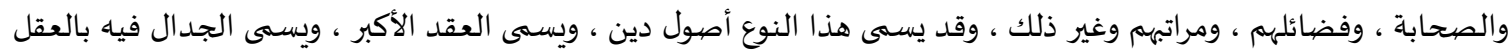

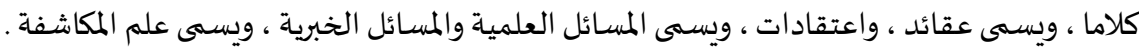

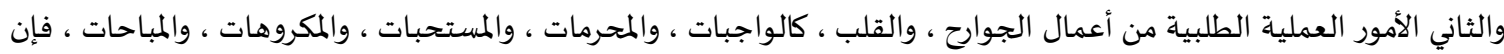

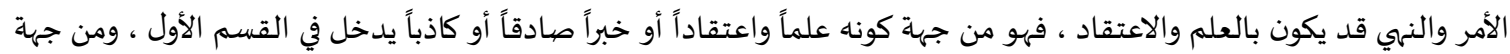

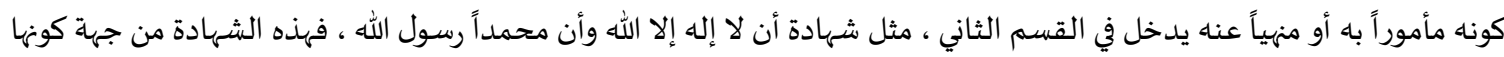

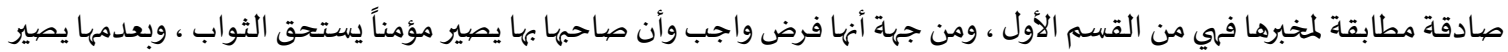

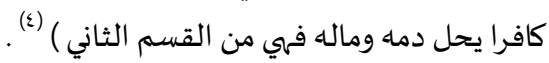

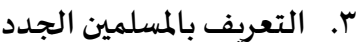
المقصهود بالمسلمين الجدد هنا : هم من دخل في الإسلام حديثاً ، بغض النظر عن الديانة السابقة التي كان عليها ، أو الزمان أو المكان الذي حصل دخوله للإسلام فيه . ثانياً : التعريف المركب لعنوان البحث : المران

بناء على ما سبق فيمكن إيضاح المراد الإجمالي للنوازل العقدية للمسلمين الجدد بأنها :

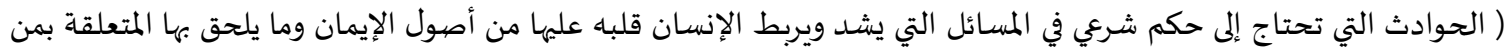

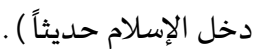

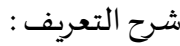
( الحوادث) : هذا القيد يخرج المسائل القديمة غير الحادثة .

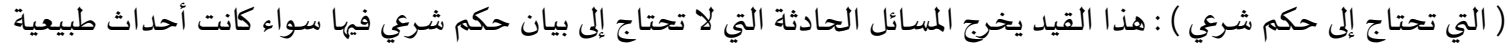

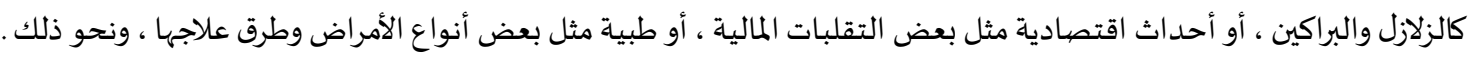

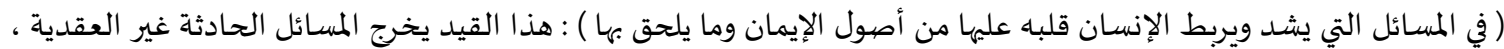

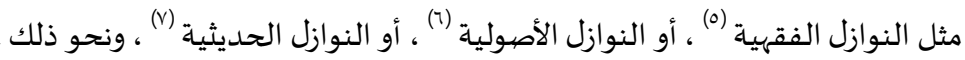
(المتعلقة بمن دخل الإسلام حديثاً ): هذا القيد يخرج النوازل العقدية المتعلقة بغير من دخل الإسلام حديثاً ، مثل بعض النالية النوازل العقدية المتعلقة بالأقليات الإسلامية ، ونحو ذلك.

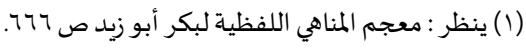

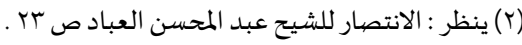

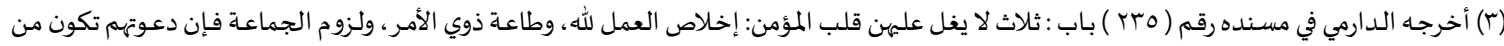

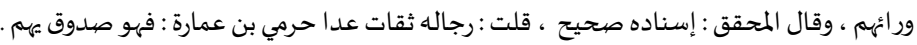

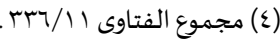
(1) (1) و والأبحاث في هذا الفتاو الباب كثيرة. (7) ومن ذلك بحث ( النوازل الأصولية ) د. أحمد الضوريحي. و (V) ومما يدخل في ذلك من النوازل استخدام التقنية الحديثة في مراتب التحمل والأداء في رواية الأحاديث ، ونحو ذلك. 


\section{المبحث الأول: وفيه بيان أهمية العناية بلدراسـة النوازل العقدية المتعلقة بالمسلمين الجددد}

تتمثل أهمية هذا الموضوع في عدة أمور يمكن اجمالها في الآتي :

أولاً : أهمية التأصيل وبيان المنهج الصحيح في التعامل مع المسائل العقدية المستجدة المتعلقة بالمسلمين الجددد ، وأهمية الإجابة عن

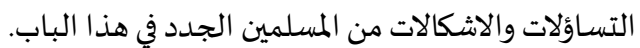
ثانياً : الإسهام في بناء منهج تطبيقي لعقيدة أهل السنة والجماعاة في النوازل والحوادث الواقعة من الاعتقادات والأفكار معرفة وحكماً ومعالجة

ثالثاً : تجلية جهود قدرة علماء الشربعة على معالجة النوازل المعاصرة.

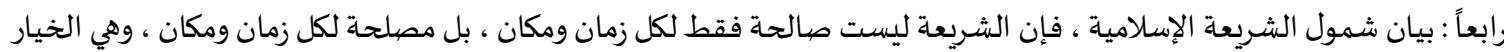
الأفضل في جميع الأزمان والأماكن ، وهذا من المقاصد الشرعية المهمَّة

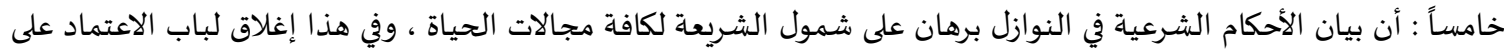
القوانين الغربية التي لا تتوافق مع الأصول الشرعية .

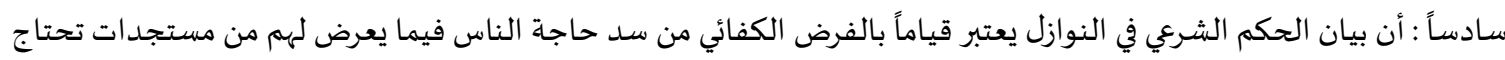

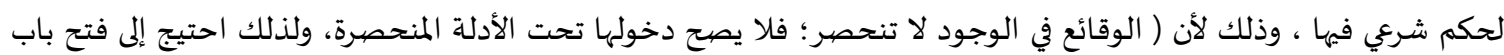

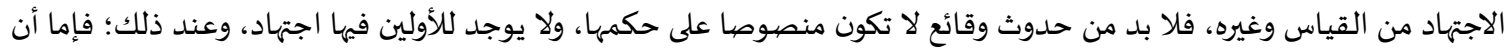

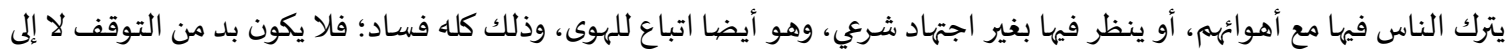

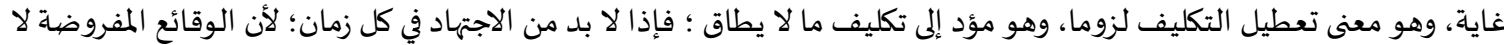

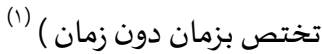

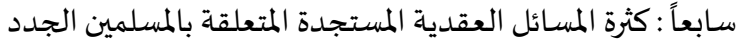

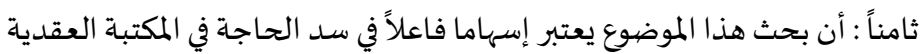

المبحث الثاني : وفيه بيان جملة من القواعد الشرعية المؤثرة في النوازل العقدية للمسلمين الجدد . وذلك أن كثيراً من النوازل العقدية المتعلقة بالمسلمين الجدد تتأثر بجملة من القواعد الشرعية التي قررها أهل العلم ، ولعل التول

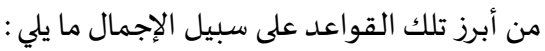

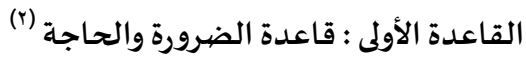
وذلك أن الضرورات والحاجيات واردة في باب النوازل العقدية للمسلمين الجدد بشكل واضحة، حيث إن كثيراً من المسلمين الجددد هم من الأقليات التي تكون في البلاد غير الإسلامية، ويكون ضعفههم في بداية دخول الإسلام ظاهر لمن خالطهم مما يستدعي الترفق بهم، ومن الضيوابط المندرجة تحت هذه القاعدة : ا. الضرورة تقدر بقدرها ، في الزمان والمكان والمقدار ، فيقتصر على الزمن الذي يدفع الضرورة قبل وقوعها أو يرفعها بعد الوقوع ، وكذا يقتصر على المكان الذي يدفع الضرورة قبل وقوعها أو يرفعها بعد الوقوع ، وكذا يقتصر على المقدار الذي يدفع الضبرورة

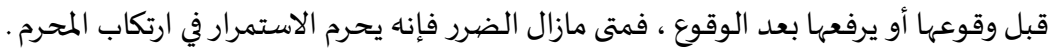

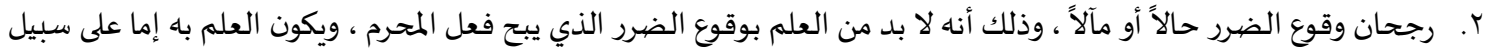

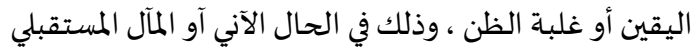

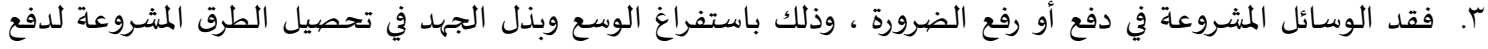

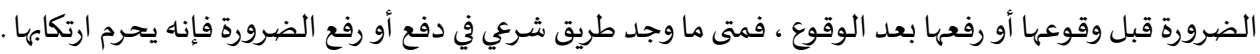
ع. ألا يترتب على فعل المحظور وقوع ضرر مثله أو أكبر ، وذلك أن المقصد الشرعي هو في تقليل المفاسد ودفع المفسدة الكبرى أو المساوية بارتكاب الصغرى .

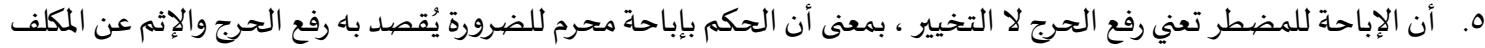
، ولا يقصد باء أنه مباح الفعل أو الترك ، بل قد يكون ارتكاب الضرورة الاحبه واجباً أو مستحباً أو مخيراً فيه . 
7 7. أن ما حرم لذاته لا يباح إلا للضرورة ، وما حرم سداً للذريعة يباح للحاجة .

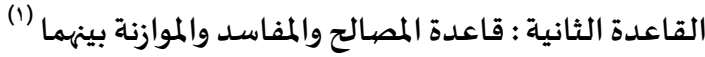

وذلك أن الموازنة بين المصالح والمفاسد واردة على المسلم في سائر أحواله ، وهي في باب النوازل العقدية للمسلمين الجدد أكثر

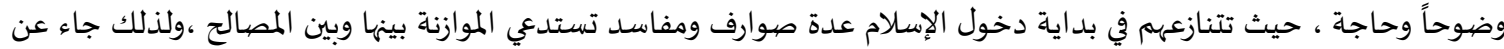

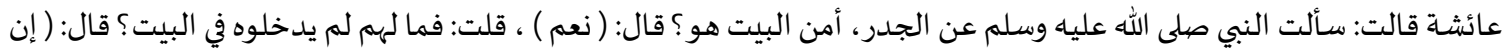
قومك قصرت بهم النفقة ) ، قلت: فما شأن باباه مرتفعا، قال: ( فعل ذاك قومك ليدخلوا من شاءوا، ويمنعوا من شاءوا، ولولا أن

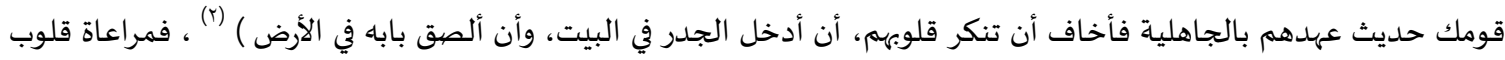
المسلمين الجدد بما تعرف والحذر مما تنكره يعتبر مطلباً شرعياً في هذا الباب ، ومن الضوابط المندرجة تحت هذه القاعدة :

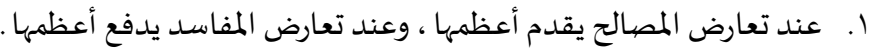

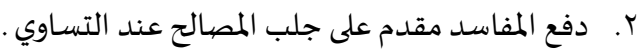

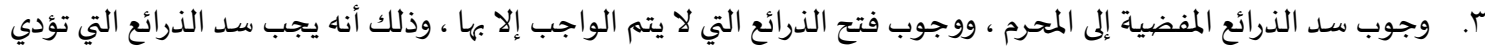

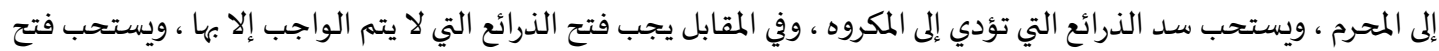
الذرائع التي لا يتم الاستحباب إلإبها .

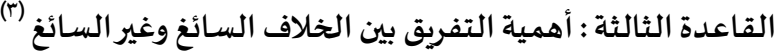

وذلك بالنظر إلى أهمية الحرص على بقاء المسلم الجديد على دين الإسلام مقابل الترخص لله فيما يسوغ فيه الخلاف، ذلك ذلك أنها

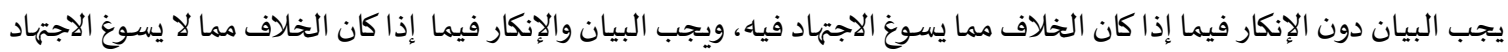

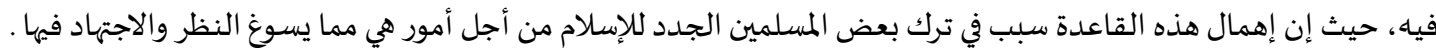

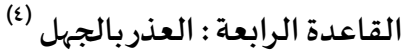
وذلك لأن واقع كثير من المسلمين الجدد وبُعد كثير منهم عن تعلم أحكام الشريعة مظنة للوقوع في المحرمات أو بعض صور

الكفر عن جهل بحكمها.

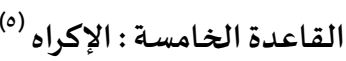

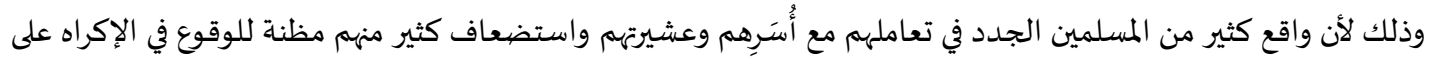

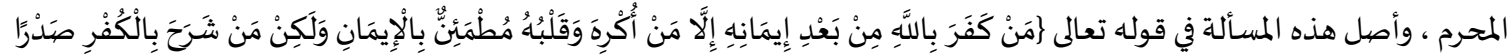

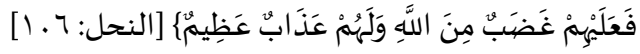
القاعدة السادسة : التفريق بين التعميم والتخصيص ومقصد ذلك هو عدم التعميم في قضايا الأعيان، بل لكل قضية حكمها ، ولكل شخص ما يناسباه، وذلك أن كثيراً من الأحكام

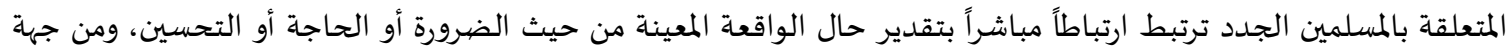

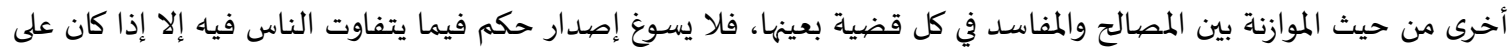
سبيل العموم والتنظير لا على سبيل التعيين والتطبيق.

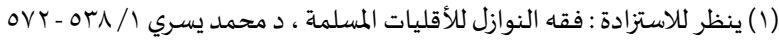

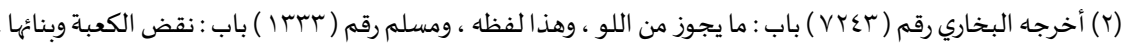

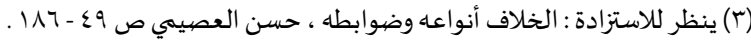

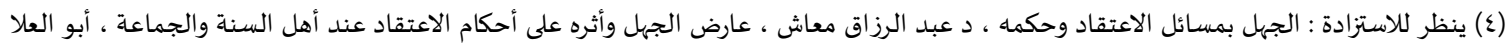

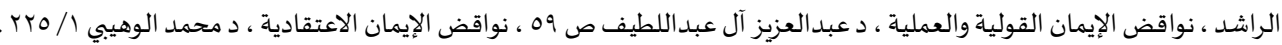

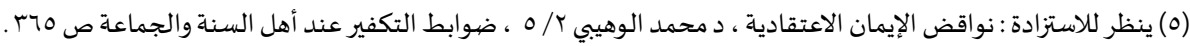


المبحث الثالث: منهجية التعامل المرحلي مع من عرف طريقه إلى الإسلام من خلال أصحاب الانحرافات

العقدية أو الفكرية الخطيرة .

وفياء مسألتان :

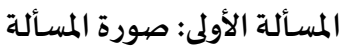

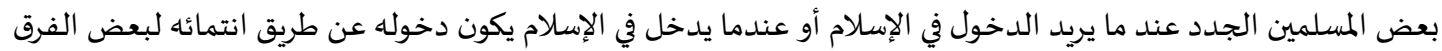

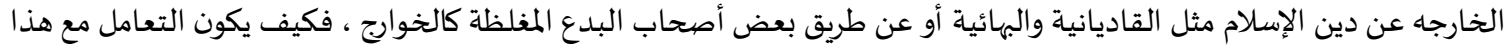

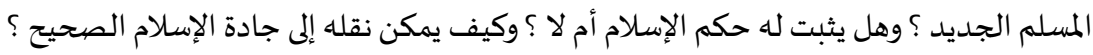
المسألة الثانية : الحكم في هذه المسألة في البداية يمكن بيان ما يثبت به دخول الإنسان لدين الإسلام وهو : اعتقاد مضمون الشهادتين ، وهو القبول المجمل لدين

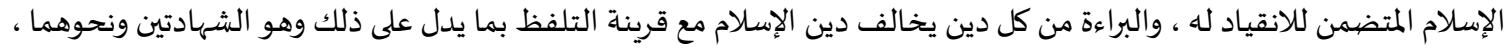

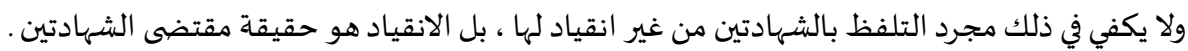

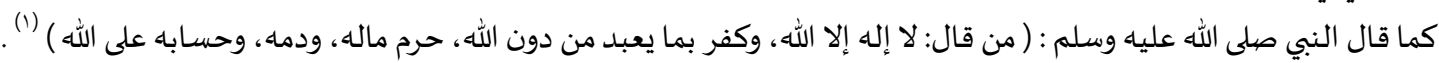

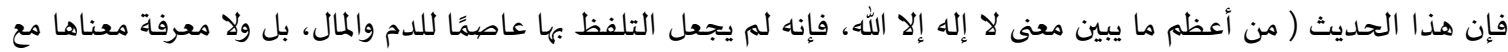

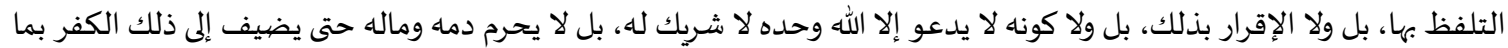

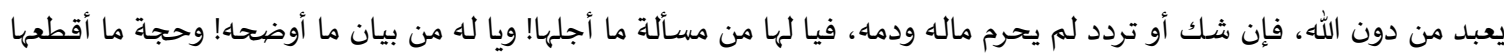

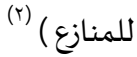
ومما يبين ذلك أن ( الإيمان ليس مجرد التصديق ... وإنما هو التصديق المستلزم للطاعة والانقياد وهكذا الهدى ليس هو مجرد المئد

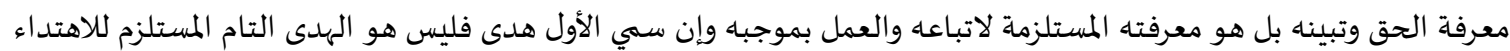

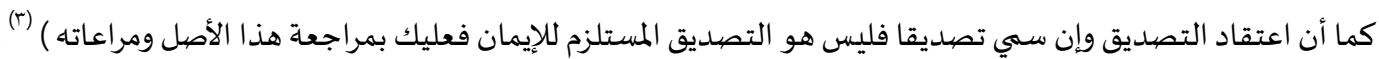

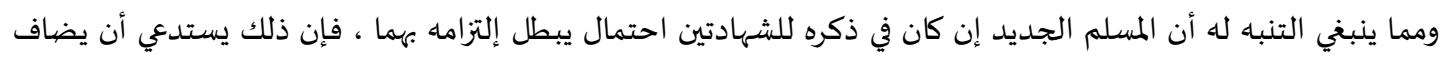

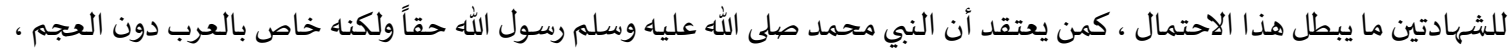

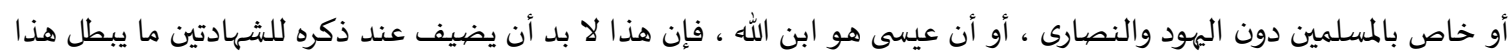

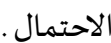

ولذلك قال الشافعي : ( الإقرار بالإيمان وجهان: فمن كان من أهل الأوثان ومن لا لا دين له يدعي أنها دين نبوة ولان كتاب فإناب فإذا شهد أن لا إله إلا الله وأن محمدا عبده ورسوله فقد أقر بالإيمان ومتى رجع عنه قتل.

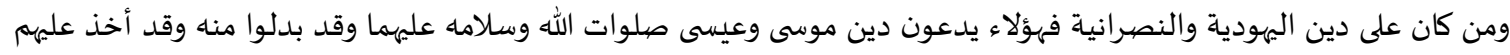

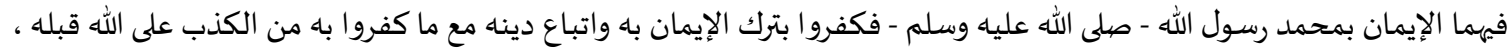

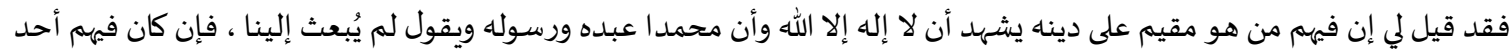

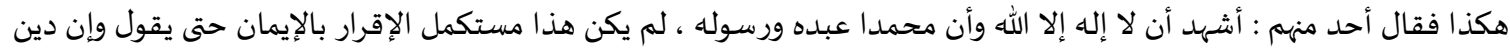

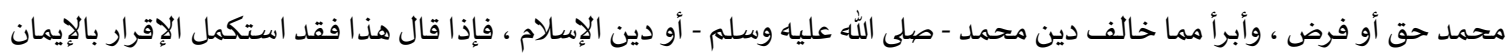

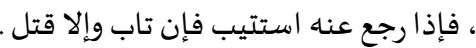

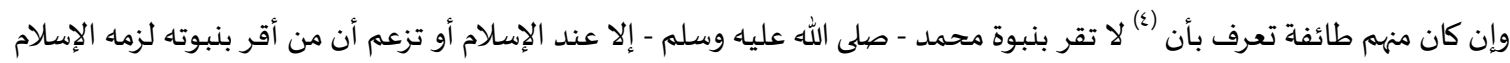

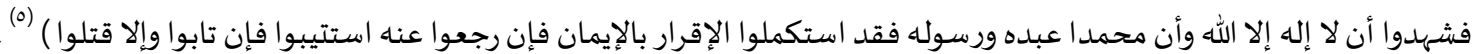

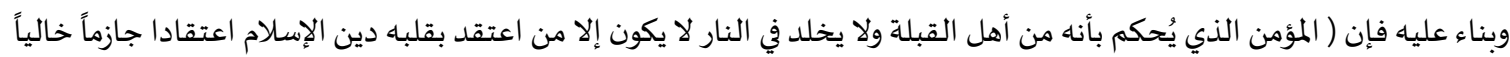

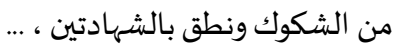

(1) (أخرجه مسلم رقم (TV ) باب الأمر بقتال الناس حتى يقولوا: لا إله إلا الله محمد رسول الله.

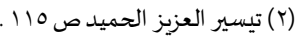

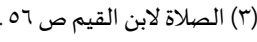

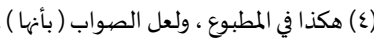

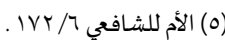


أما إذا أتى بالشهادتين فلا يشترط معهما أن يقول وأنا بريء من كل دين خالف الإسلام إلا إذا كان من الكفار الذين يعتقدون

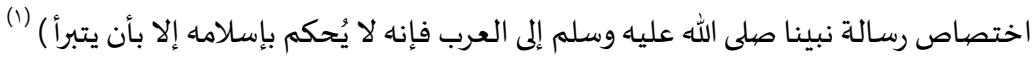

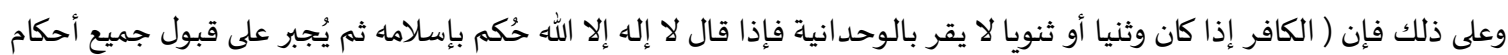

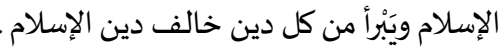

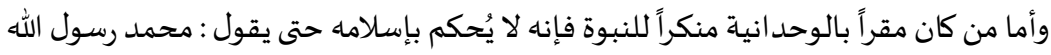

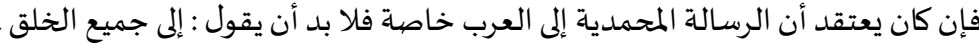

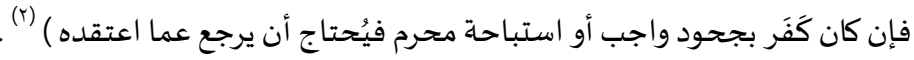
ولذلك فإن من أراد الدخول في الإسلام وكان من أهل الكفر وهو (غير موحد فالمطالبة متوجهة إليه بكل واحدة من الشهادتين على

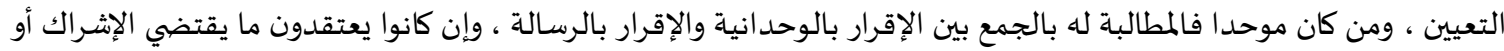

يستلزمه كمن يقول ببنوة عزير أو يعتقد التشبيه فتكون مطالبتهم بالتوحيد لنفي ما يلزم من عقائدهم ) (r) ل. وبناء على ما سبق فإن الأصل للدخول في الإسلام هو الإقرار بمضمون الشون الشهادتين والانقياد لهما مع قرينة التلفظ بالشهادتين ونحوهما

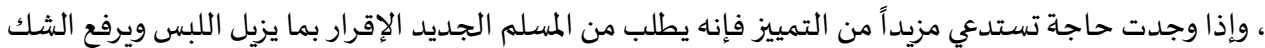
فإذا دخل المسلم الجديد للإسلام عن طريق أصحاب الانحرافات العقدية أو الفكرية الخطيرة التي لا يثبت معها عقد الإسلام كالقاديانية أو البهائية أو بعض طوائف الرافضاة ونحو ذلك فإناه يبين لله حقيقة هذه الانحرافات وأنه لا يبقى معها عقد الإسلام وأنها

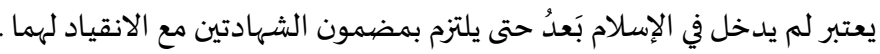

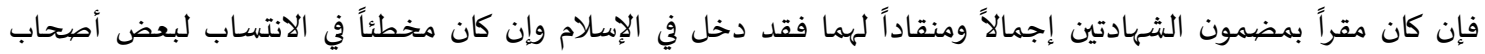
الانحرافات الخطيرة كالخوارج.

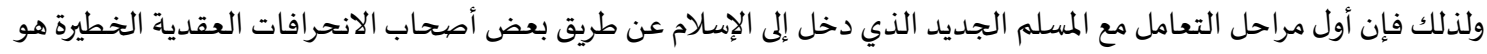

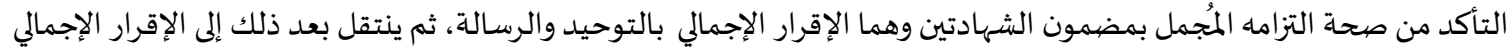

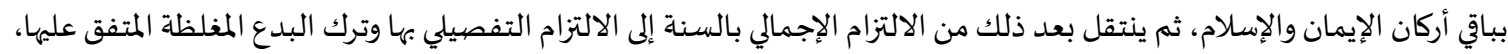
حتى يستكمل مراتب الدين، فإن ( الداخل في الإسلام لا يمكن حين دخوله أن يُلقن جميع شرائعه ويؤمر بها كلها.

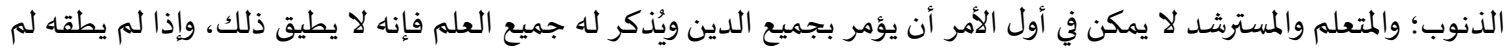

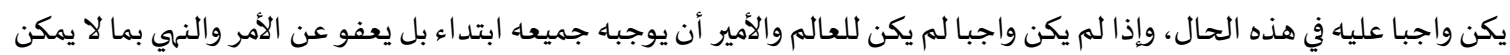
علماه وعمله إلى وقت الإمكان، كما عفا الرسول عما عفا عنه إلى وقت بيانه، ولا يكون ذلك من باب إقرار المحرمات وترك الأمر

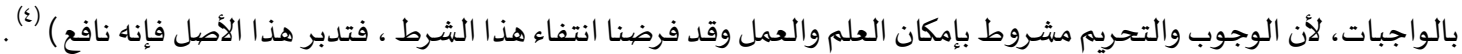
ومن أمثلة أصحاب الانحرافات العقدية والفكرية الخطيرة والتي تنتشر في القارة الأمريكية على تفاوت بينهم في دركات الانحراف، وقد

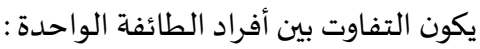

القاديانية (0)

البابية (7)

الإسماعيلية (v)

الشيعة الاسيماعلية

(9) العلمانية

(الأحباش العلماني

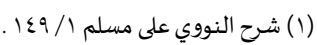

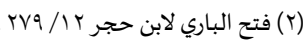

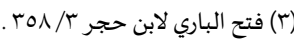

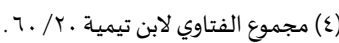

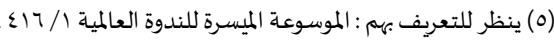

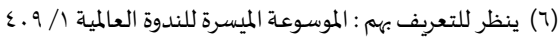

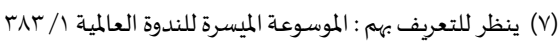

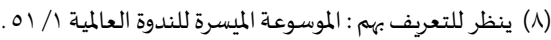

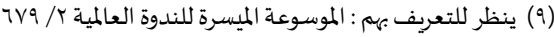




$$
\begin{aligned}
& \text { غلاة الصوفية ومنهم أصحاب الحلول ووحدة الوجود (r) }
\end{aligned}
$$

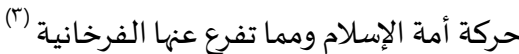

$$
\begin{aligned}
& \text { المبحث الرابع : النوازل المتعلقة بنطق الشهادتين }
\end{aligned}
$$

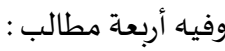

$$
\begin{aligned}
& \text { المطلب الأول : الدخول في الإسلام بنطق لفظ عربي غيز الشهادتين } \\
& \text { وفياه مسألتان : }
\end{aligned}
$$

وذلك فيما إذا نطق الشخص عند إرادة دخوله الإسلام بلفظ عربي غير الشهادتين ، كأن يقول : آمنت بالله ، أو أسلمت ، أو الو الوال

دخلت في الإسلام ، أو نحو ذلك من العبارات ، فهل يكون بذلك مسلماً ؟

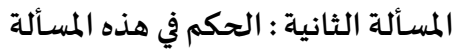

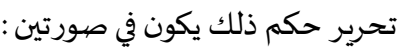

إن كان هذا الشخص مقر بمضمون الشهادتين وترك التلفظ بالشهادتين لعذر مع قدرته على النطق بهما ، فهذا معذور ويصح إسلامها

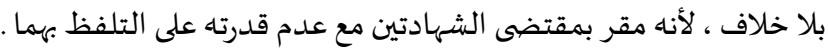

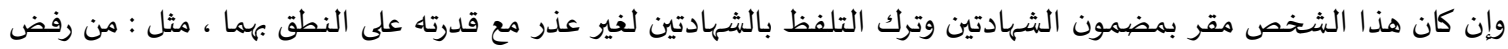

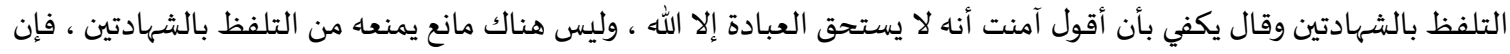

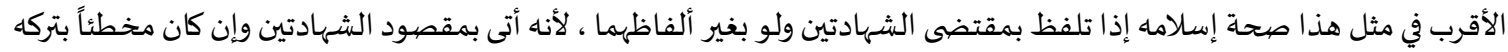

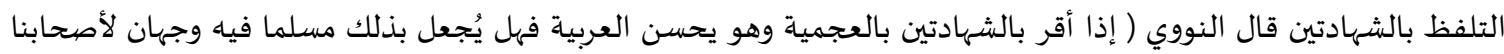

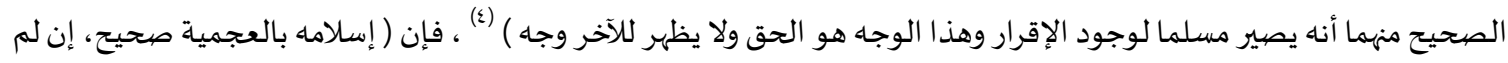

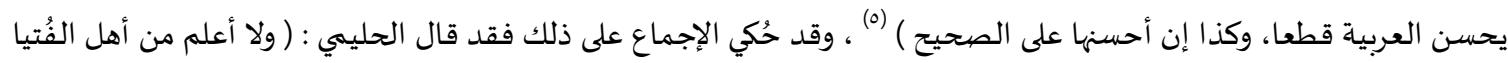

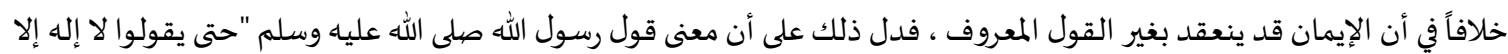

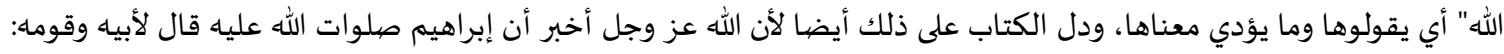

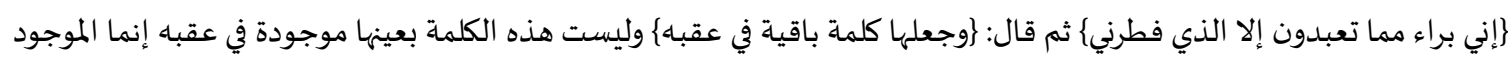

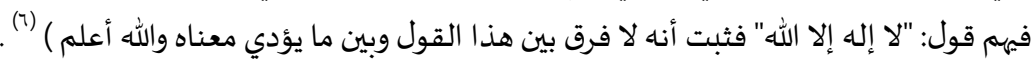

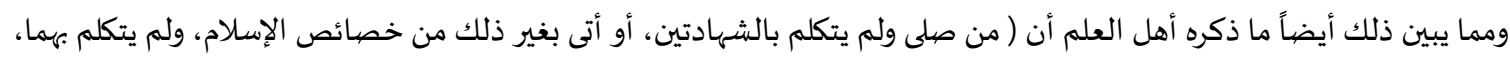

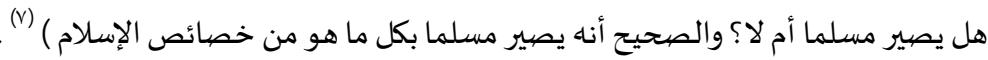

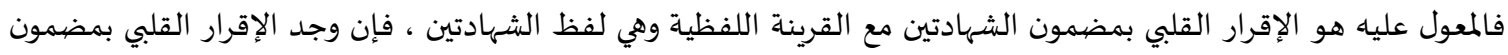

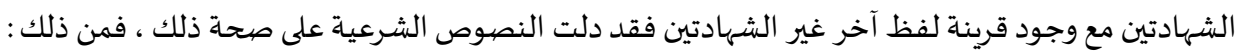

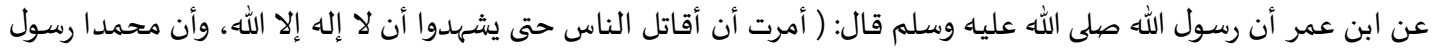
(الله (الن وعن سعيد بن المسيب، عن أبيه أنه أخبره: أنه لما حضرت أبا طالب الوفاة جاءه رسول الله صلى الله عليه وسلم، فوجد عنده أبا

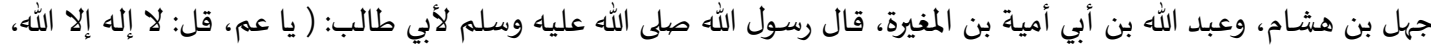

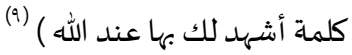

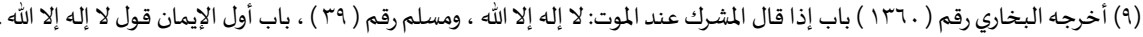


• وقول النبي صلى الله عليه وسلم : ( من قال: لا إله إلا الله، وكفر بما يعبد من دون الله، حرم ماله، ودماه، وحسابه على الله ) (1) عن ابن عباس رضي الله عنهما: أن رسول الله صلى الله عليه وسلم لما بعث معاذا رضي الله عنه على اليمن، قال: ( إنك تقدم على

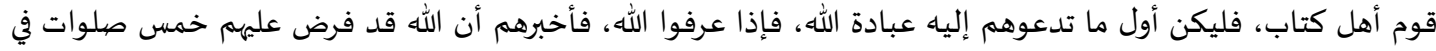

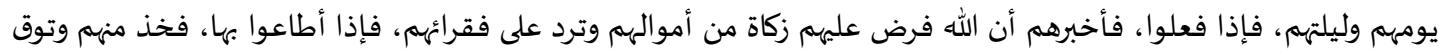

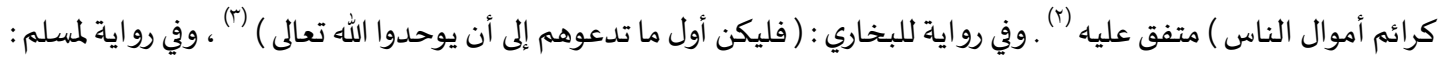

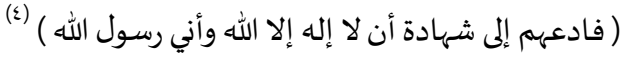

وعن بهز بن حكيم، عن أبياه، عن جده، قال: قلت: يا نبي الله، ما أتيتك حتى حلفت أكثر من عددهن لأصهابع يدياه أن لا آتيك ولا

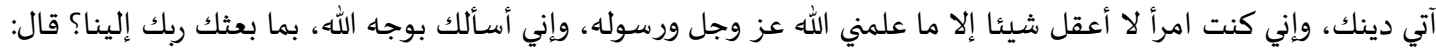

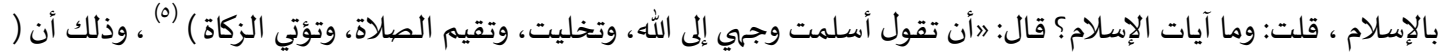

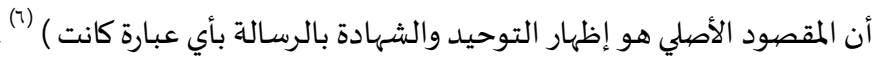

وعن ابن عمر قال: بعث النبي صلى الله عليه وسلم خالد بن الوليد إلى بني جذيمة، فدعاهم إلى الإسلام، فلم يحسنوا أن يقولوا:

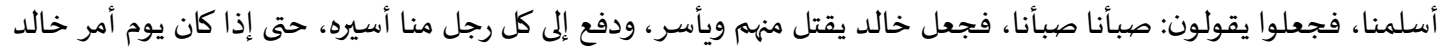
أن يقتل كل رجل منا أسيره ، فقلت: والله لا أقتل أسيري، ولا يقتل رجل من أصحابي أسيره، حتى قدمنا فئا على النبي صلى الله عليه

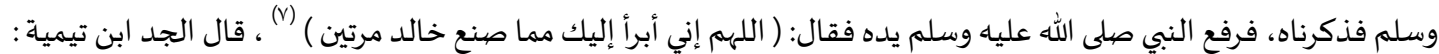

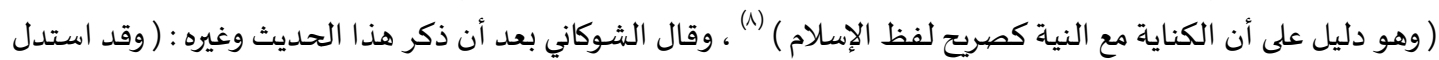

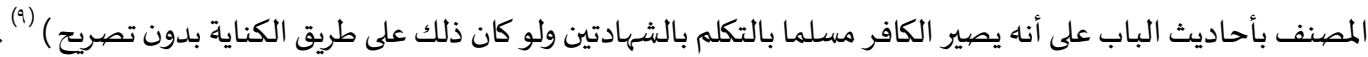

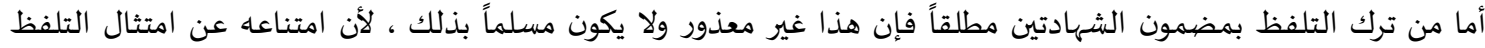

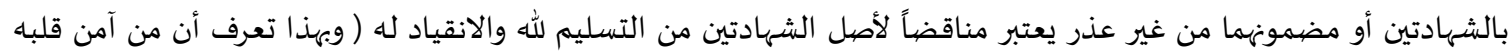

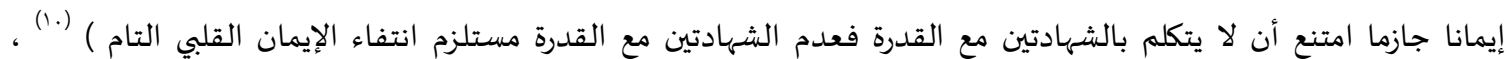
و(الشهادتان إذا لم يتكلم بهما مع القدرة فهو كافر باتفاق المسلمين وهو كافر باطنا وظاهرا عند سلف الأمة وأئمتها وجماهير علمائها )

$$
\text { المطلب الثاني : الدخول في الإسلام بلفظ غيرعربي }
$$

وبيان ذلك أنه إذا نطق الشخص الذي لا يتكلم العربية عند إرادة دخوله الإسلام بلفظ غير عربي سواء كان هذا اللفظ بمضمون الشهادتين كأن ينطق باللغة الإنجليزية بنفس مضمون الشهادتين ، أو ينطق باللغة الإنجليزية بغير مضمون الشهادتين ، فهل يكون بذلك مسلماً ؟ المسألة الثانية : الحكم في هذه المسألة تحرير حكم ذلك يكون في صورتين :

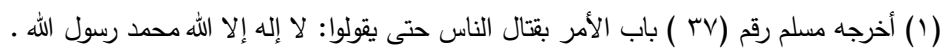

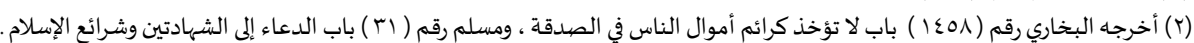

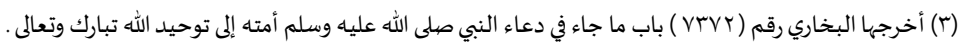

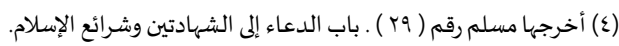

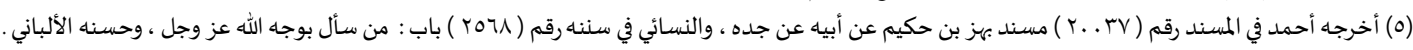

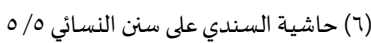

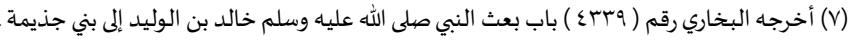

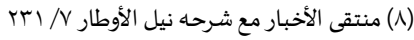

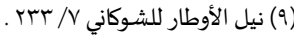

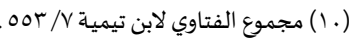

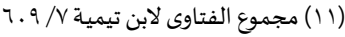




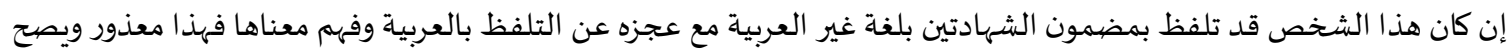

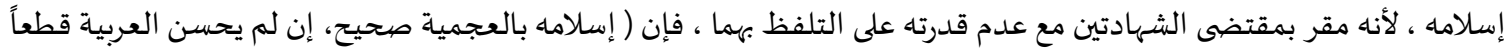

وإن كان هذا الشخص قد تلفظ بمضمون غير الشهادتين بلغة غير العربية مع عجزه عن التلفظ بالعربية وفهم معناها ، كأن يقر بمضمون لفظ ( آمنت بالله ) فإن الأقرب في مثل هذا صحة إسلامه إذا تلفظ بمقتضى الشهادتين ولو بغير ألفاظهما ، لأنه أتى هانى

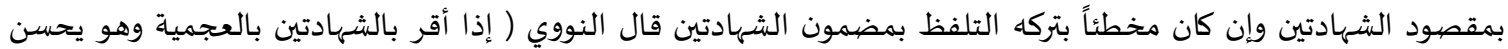

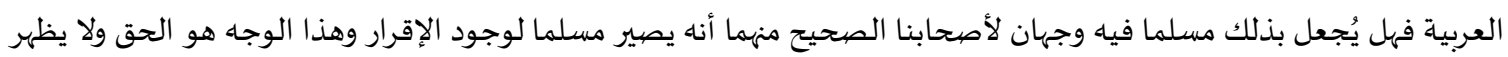
للآخر وجاه ) (r) ، وإذا كان من أقر بمضمون بأ الشهادتين بغير العربية مع قدرته على العربية يصح إسلامه مع تفاوت دلالة الألفاظ بينهما

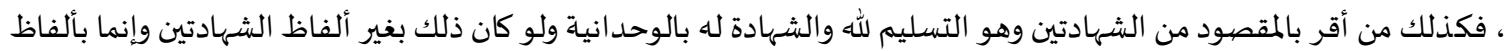

تؤدي المقصود من الشهادتين .

أما من ترك التلفظ بمضمون الشهادتين مطلقاً فإن هذا غير معذور ولا يكون مسلماً بذلك ، لأن امتناعها عن امتثال التلفظ

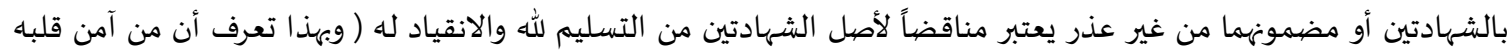

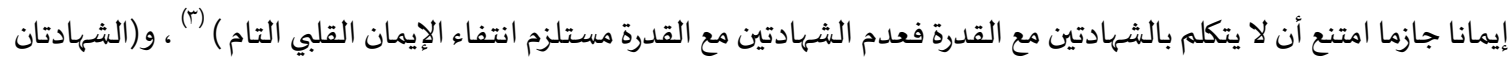

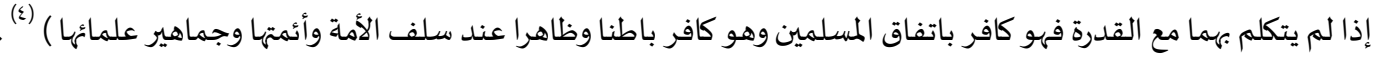
المطلب الثالث : التلفظ بالشهادتين بالعربية لمن لا يتكلم العربية من غير فهم لمعناها ومقتضـاها

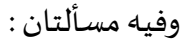

المسألة الأولى : صهورة المسألة : ألمانة

بيان ذلك أنه إذا نطق الشخص المُ الذي لا يتكلم العربية عند إرادة دخوله الإسلام بلفظ الشهادتين من غير فهم وتصديق لمعناها

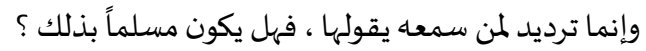

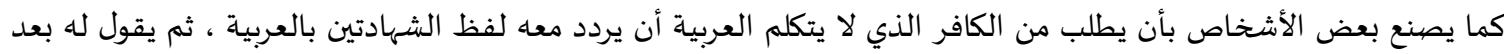
الفراغ من الترديد : أصبحت الآن مسلماً.

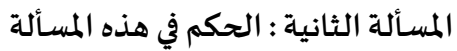

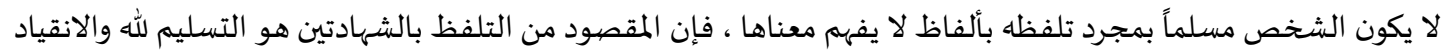

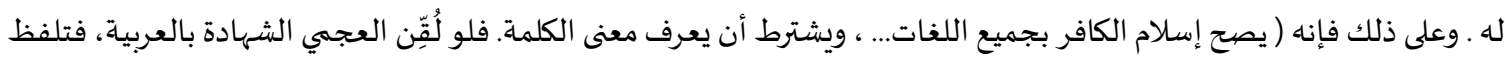

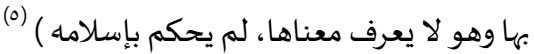

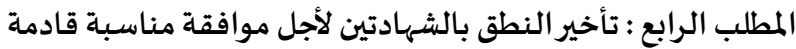
وفياء مسألتان :

المسألة الأولى : صهورة المسألة : مبانة

قد يرغب بعض من يريد الإسلام أن يدخل في الإسلام فيؤجل بعض الناس نطقه للشهادتين لأجل موافقة مناسبة قادماة، مثل

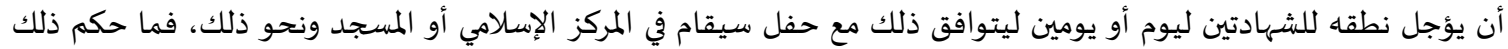
التصرف؟ المسألة الثانية : الحكم في هذه المسألة

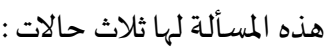

الأول: أن يُؤجل بيان مفهوم الشهادتين لهذا الشخص الراغب في دخول الإسلام

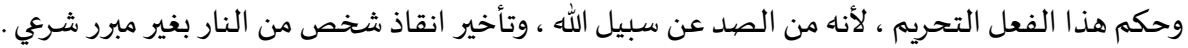
وأما حكم هذا الشخص فإن مات قبل إقراره بمضمون الشهادتين فليس له حكم الإسلام، لأنه لم يقر بمضيمون الشهادتين.

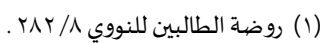

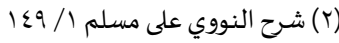

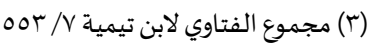

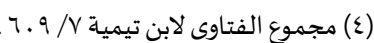

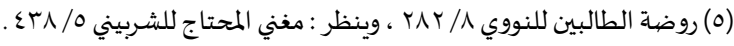

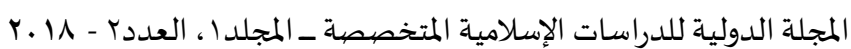


الثاني: أن يتم بيان مفهوم الشهادتين لهذا الشخص فيقر بذلك ، لكن يتم تأجيل نطقه بالشهادتين لمناسبة قادمة يعلن فيها إسلامه

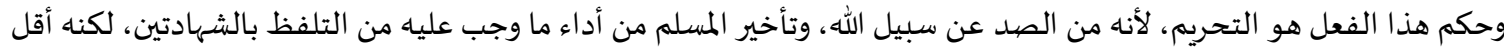
تحريماً من الحالة الأولى . وأما حكم هذا الشخص فإن مات بعد إقراره بمضمون الاون الشهادتين وقبل نطقه بالشهادتين أو ما يقوم مقامهما فله حكم الإسلام، لأنها

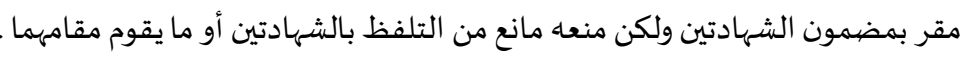
الحالة الثالثة : أن يتم بيان مفهوم الشهادتين لهذا الشخص فيقر بذلك ، وينطق بالشهادتين أو ما يقوم مقامهما ، ثم يعيد نطقه

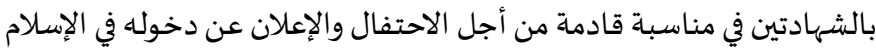
وحكم هذا الفعل هو الجواز ، لحصول الدخول في الإسلام بإقراره بمضمون الشهادتين وتلفظه بذلك ، ولعدم المحذور من تكرار تلفظه بالشهادتين في المناسبات القادمة . وأما حكم هذا الشخص فهو الإسلام حيث أقر بمضمون الشهادتين وتلفظ بذلك في وقته ، ولا يوجد محذور من إعادته التلفظ بالشهادتين في المناسبات القادمة .

المبحث الخـامس : النوازل المتعلقة بالدخول الكامل أو الجزئي للإسلام •

وفياه مطلبان : المطلب الأول : اشتراط فعل بعض المحرمات أو ترك بعض فرائض الدين

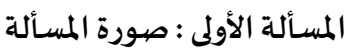

نظراً لجهل بعض من يريد الدخول في الإسلام ، أو لغلبة معصية من المعاصي عليه ، فإنه يشترط عند دخوله في الإسلام

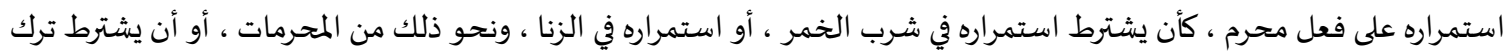
واجب من الواجبات ، كأن يشترط ترك الزكاه ، أو ترك الصيام ، ونحو ذلك من الواجبات. فهل يصح إسلامه بذلك الشرط ؟

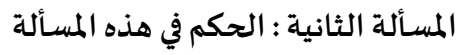
تحرير حكم ذلك يكون في صورتين : إن كان هذا الشخص اشترط استحلال هذا المحرم أو عدم إلتزامه بأوامر الله فهذا لا يصح إسلامه لأن ذلك مناقض لأصل الشهرن الشهادتين من التسليم لله والانقياد له ه. وإن كان اشتراطه هو استمراره في فعل المحرم مع عدم استحلاله له فهذا يصح إسلامها لأن دخوله للإسلام مع فعله للمحرمات خير من

فعن أنس، أن رسول الله صلى الله عليه وسلم قال لرجل: ( أسلم ، قال: أجدني كارها. قال: أسلم وإن كنت كارها ) (1) وعن جابر أن ثقيف لما بايعت اشترطت على النبي صلى الله عليه وسلم، أن لا صدقة عليها، ولا جهاد، وأنه سمع النبي صلى الله عليه

وسلم بعد ذلك يقول: ( سيتصدقون، ويجاهدون إذا أسلموا ) (r) .

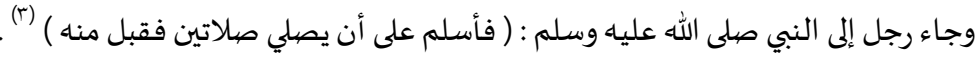

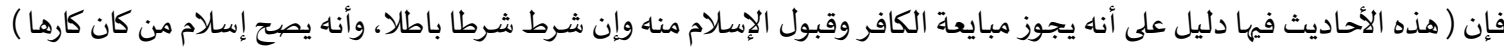

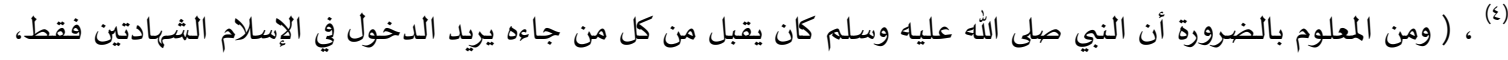

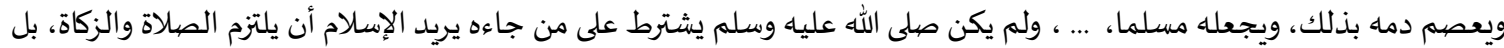

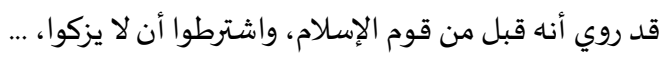

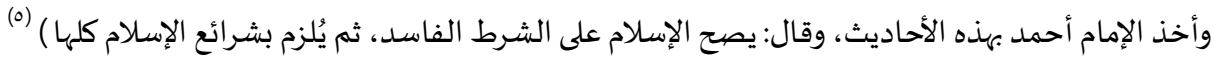
ويُشكل على ما سبق ما جاء عن عثمان بن أبي العاص، أنمل هذه الاحد، وفد ثقيف قدموا على رسول الله صلى الله عليه وسلم، فأنزلهم المسجد ليكون أرق لقلوبهم، فاشترطوا على النبي صلى الله عليه وسلم أن لا يحشروا، ولا يعشروا، ولا يجبوا (') ، ولا يستعمل عليهم عليه

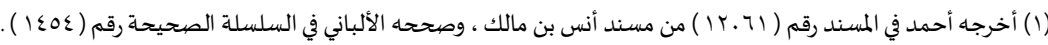

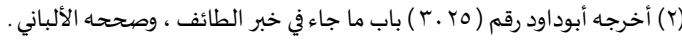

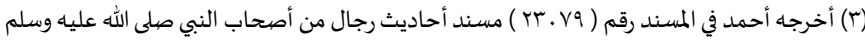

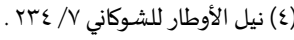

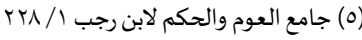


غيرهم، قال: فقال: ( إن لكم أن لا تحشروا، ولا تعشرو ا، ولا يستعمل عليكم غيركم ، وقال النبي صلى الله عليه وسلم: لا خير في دين لا

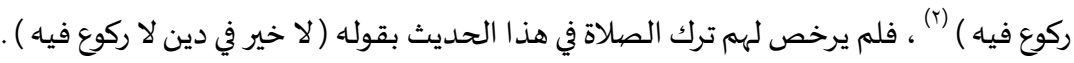

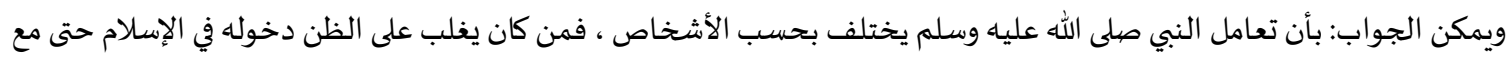

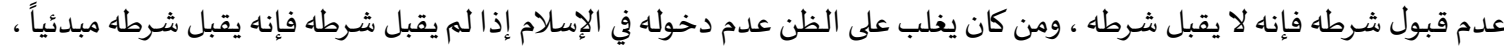

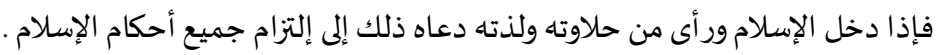

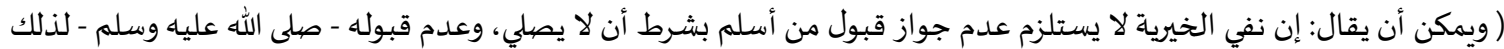

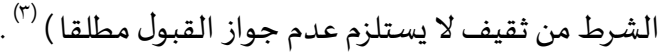

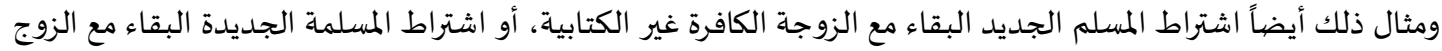

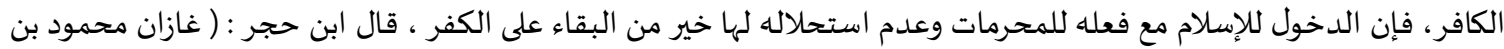

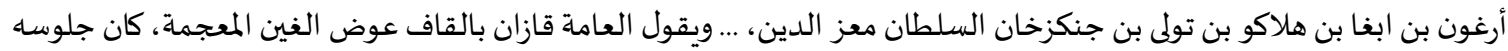

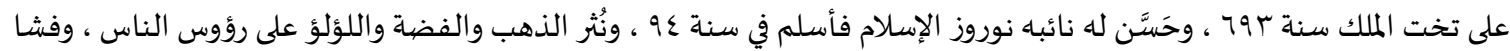

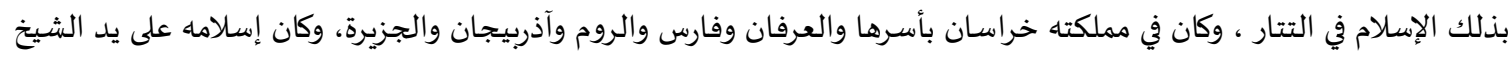

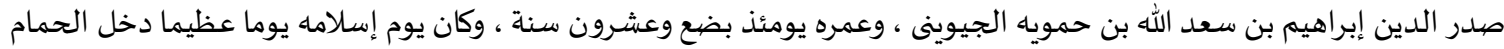

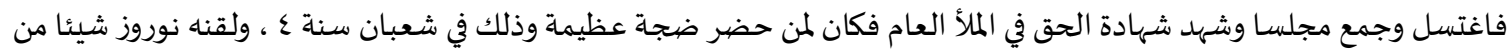

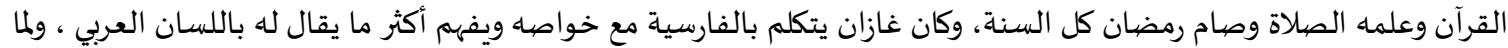

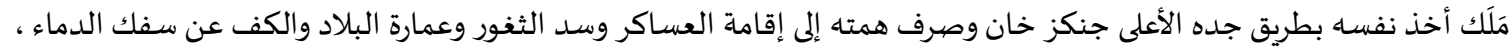

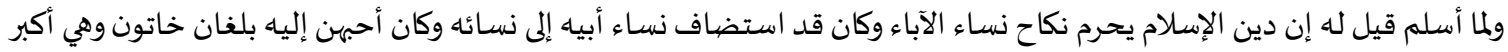

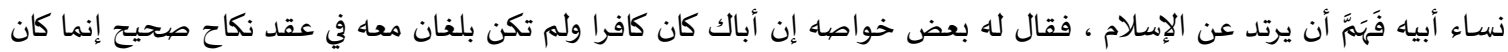

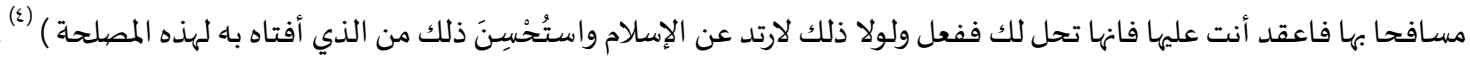

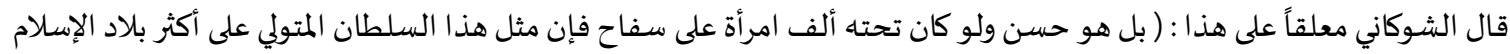
في إسلامه من المصلحة ما يُسَِّّغ ما هو أكبر من ذلك حيث يؤدى التحريج عليه والمشي معاه على أمر الحق إلى ردته فرحم الله ذلك

أنه يسوغ الدخول في الإسلام مع ترك بعض واجباته أو فعل بعض محظوراته ، فإن النبي صلى الله عليه وسلم كان يأمر بأركان

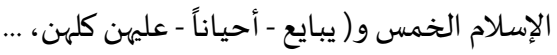

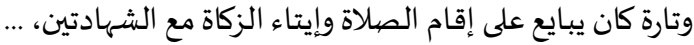

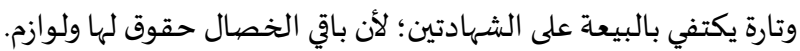
وتارة كان يقتصر في المبايعة على الشهادتين فقط، لأنهما رأس الإسلام، وسائر الأعمال تبع لهائا.

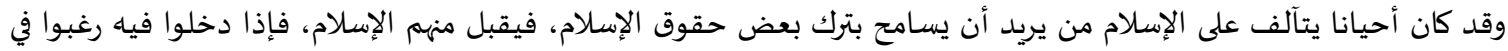
الإسلام فقاموا بحقوقه وواجباته كلها ...

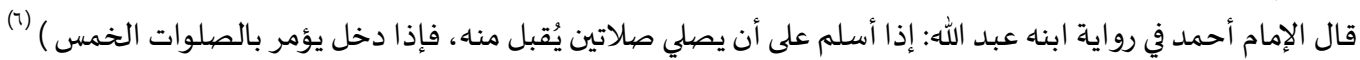

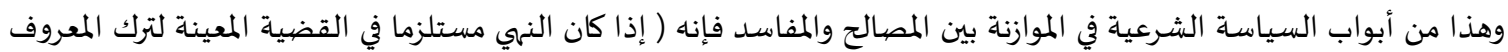

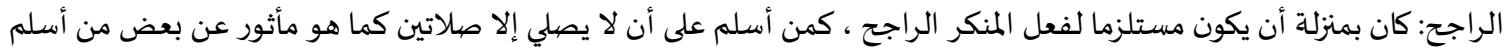

( (1) (والمراد بالحشر جمعهه إلى الجهاد والنفير إليه، وبقوله: " يعشروا " أخذ العشور من أموالهم صدقة، وبقوله: " ولا يجبوا " بفتح الجيم وضم الباء الموحدة المشددة، وأصل

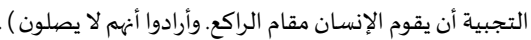

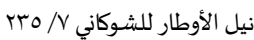

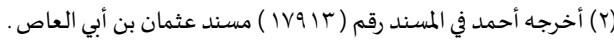

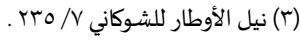

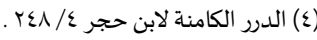

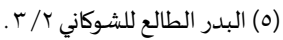

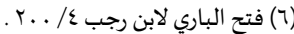


على عهد النبي صهلى الله عليه وسلم ، أو أسلم بعض الملوك المسلطين وهو يشرب الخمر أو يفعل بعض المحرمات ، ولو نهى عن ذلك ارتد عن الإسلام.

ففرق بين ترك العالم أو الأمير لنهي بعض الناس عن الشيء إذا كان في النهي مفسدة راجحة وبين إذنه في فعله ، وهذا يختلف باختلاف الأحوال) (1)

وهذا باب من أبواب تأليف القلوب على الإسلام ، حيث بوب بعض أهل العلم على بعض أحاديث هذا الباب بما يدل على ذلك (r) .

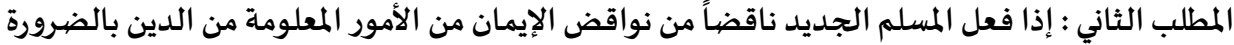

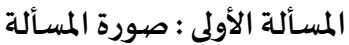
قد يقع المسلم الجديد في ناقض من نواقض الإيمان بإنكاره أمراً معلوماً من الدين بالضرورة ، كإنكار تحريم الزنا ، أو شرب

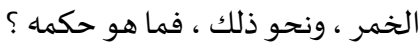

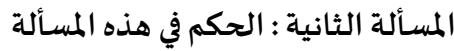

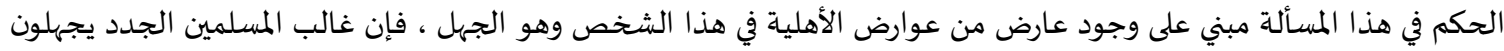

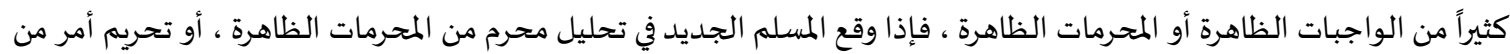

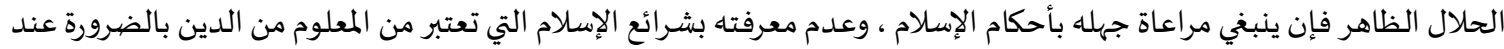

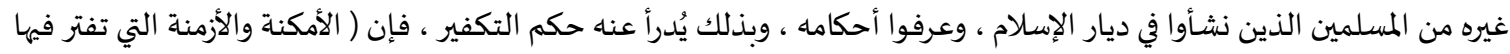

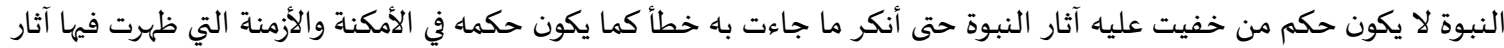

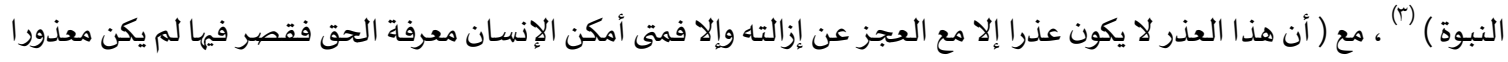

وذلك أن التكفير من جنس الوعيد ، فإنه وإن كان القول تكذيبا لما قاله الرسول صلى الله عليه وسلم ، لكن قد يكون الرجل

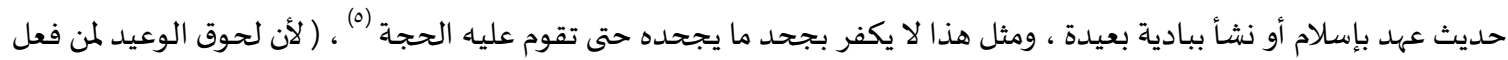

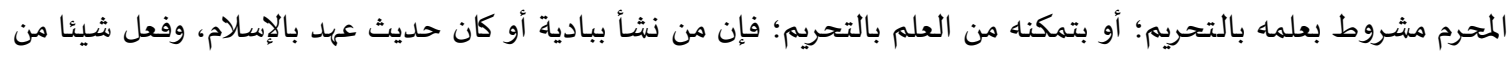

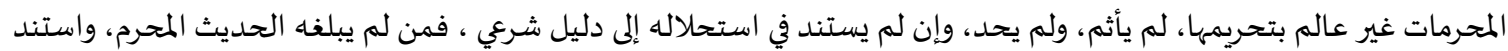

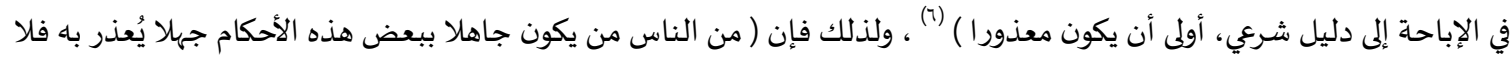

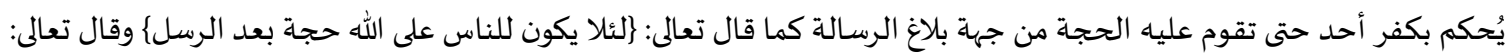

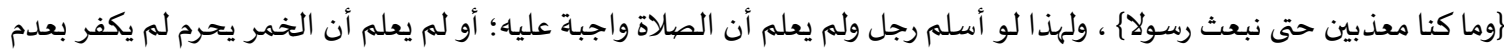

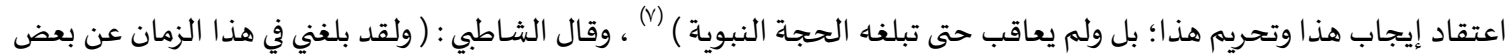

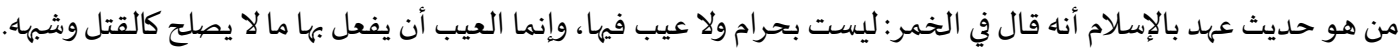

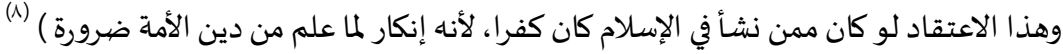

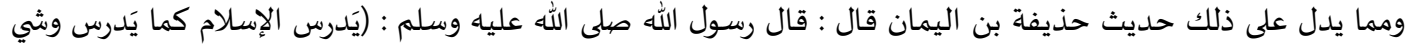

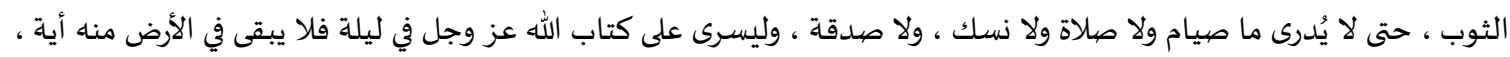

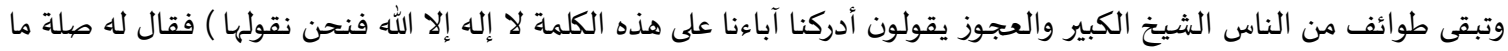

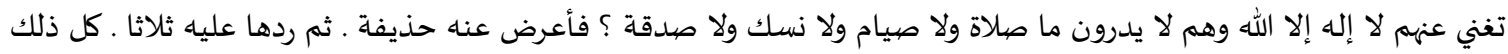

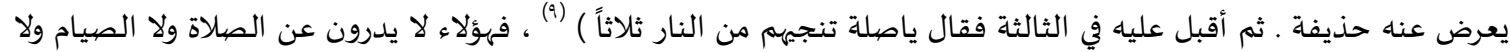
النسك من شعائر الإسلام الظاهرة ، ومع ذلك تنجيهم كلمة التوحيد من النار لغربة الدين في زمنهم.

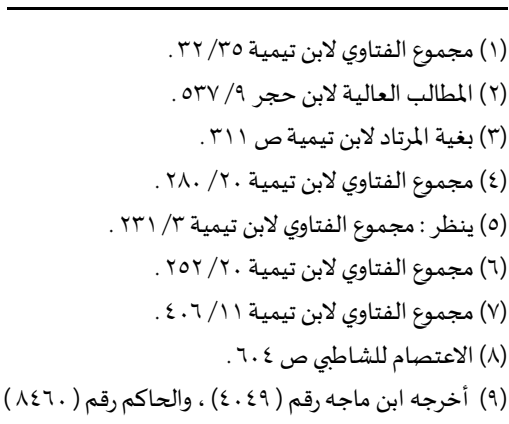

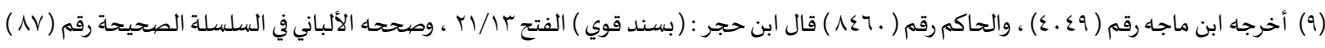


وكذلك فإن بعض من كان مع النبي صلى الله عليه وسلم ممن هو حديث عهد بالإسلام قد صهدر منه قريب من هذا ، فعن سنان بن أبي

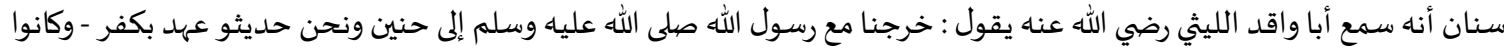

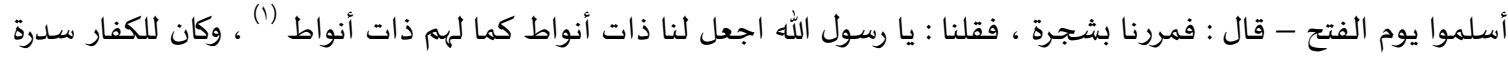

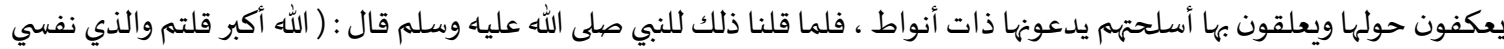

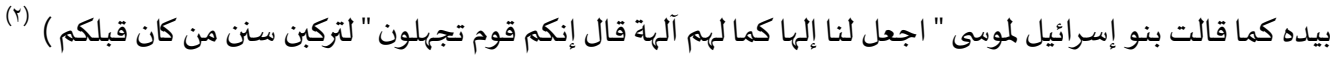

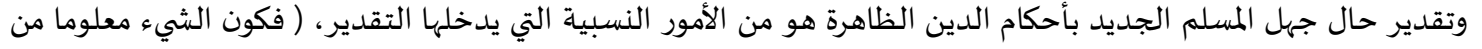

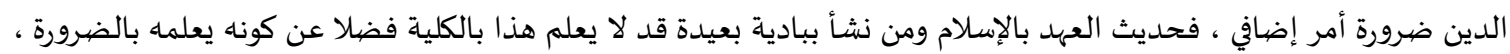

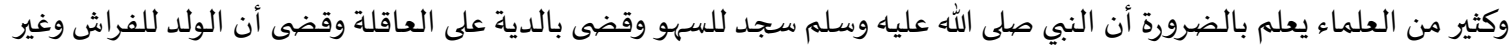

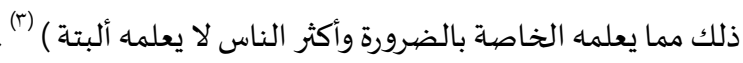

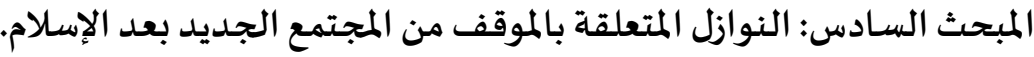 \\ وفيه مطلب واحد : الإسرار أو الإعلان عند الدخول في الإسلام \\ وفيه مسألتان :

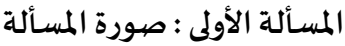

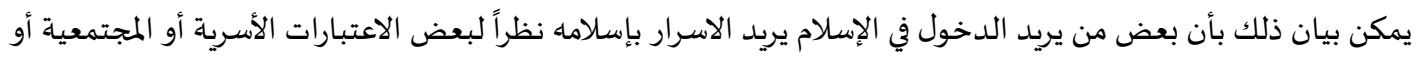

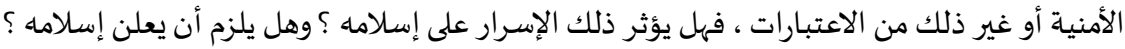

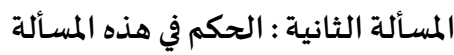

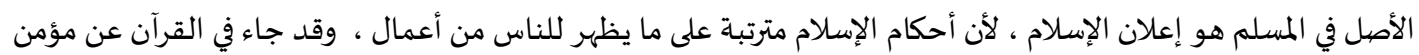

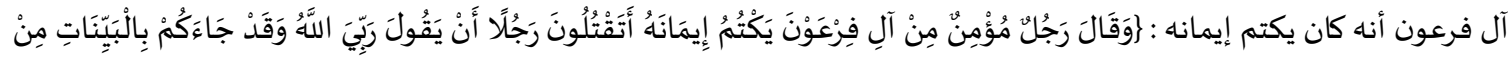

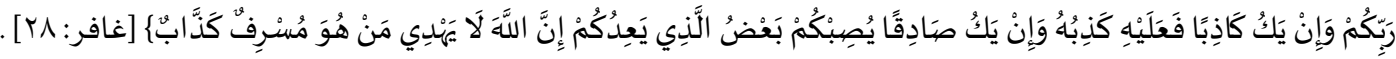

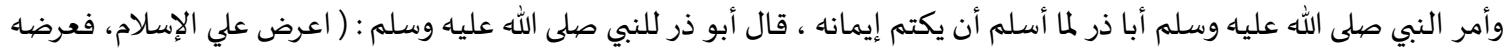

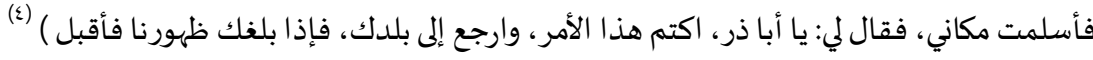

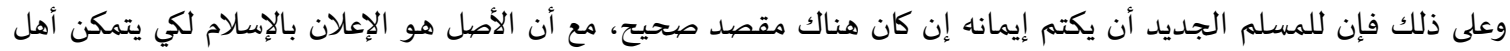

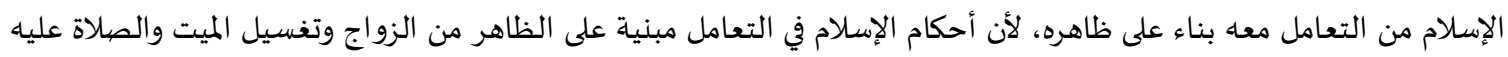

ودفنه في مقابر المسلمين ونحو ذلك.

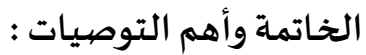

في ختام هذا البحث أحمد الله على ما وفق وأعان ، وأشير إلى النتائج والتوصيات التالية :

النتائج:

ا. أن المراد الإجمالي للنوازل العقدية للمسلم الجديد هو : ( الحوادث التي تحتاج إلى حكم شرعي في المسائل التي يشد ويربط

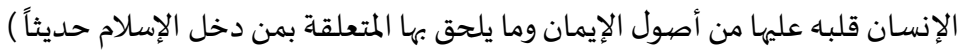

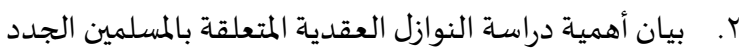

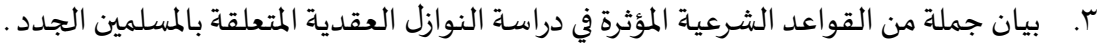

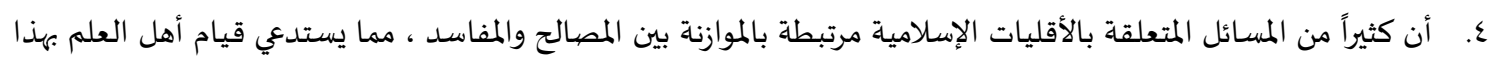

الواجب في البيان للأمة ، وإحجام من ليس لديه علم شرعي عن الخوض في هذه المسائل.

(1) هي اسم شجرة بعينها من شجر السمر كانت للمشركين تعبد من دون الله ويعلقون بها سلاحهم تبركاً ويعكفون حولها فسألوه أن يجعل لهم مثلها فنهاهم عن ذلك.

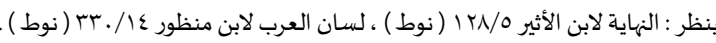

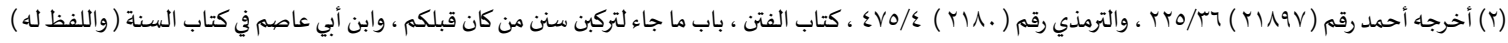

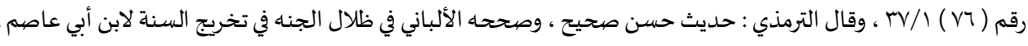

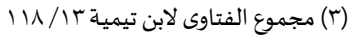

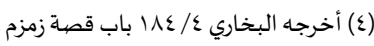

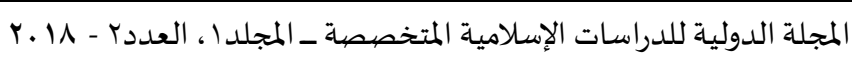


ه. أن منهجية التعامل المرحلي مع من عرف طريقه إلى الإسلام من خلال أصحاب الانحرافات العقدية أو الفكرية الخطيرة فيه

تفصيل من حيث ثبوت عقد الإسلام له أم لا.

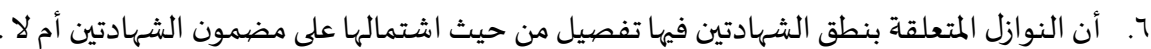

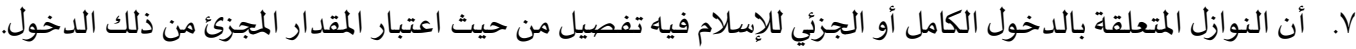

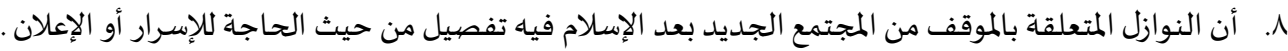

التوصيات: 1. ضرورة العناية بتعليم الأحكام العقدية لمن يتصدرون لدعوة المسلمين الجدد.

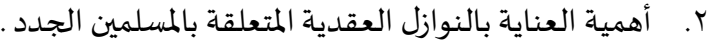

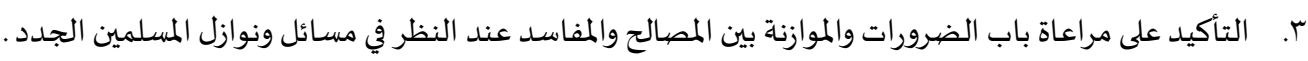
ع. أهمية مراعاة عوارض الأهلية عند البحث في مسائل المسلمين الجدود .

المراجع: القرآن الكريم.

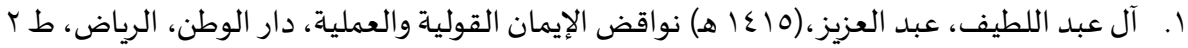

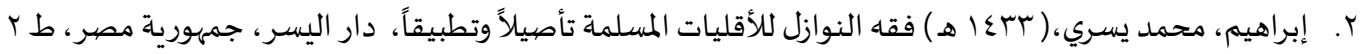
r. ابن الأثير، أبي السعادات المبارك بن محمد الجزري، النهاية في غريب الحديث والأثر، تحقيق: محمود الطناحي وآخرون، دار

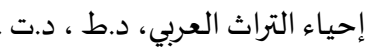

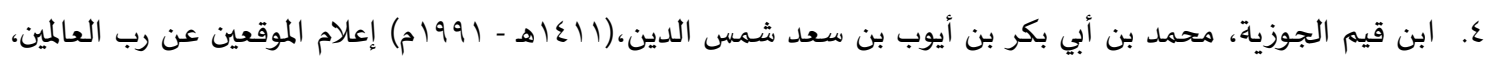

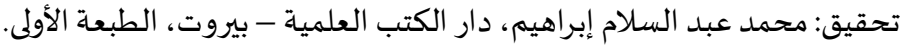

0. ابن قيم الجوزية، محمد بن أبي بكر بن أيوب بن سعد شمس الدين، الصعلاة وأحكام تاركها، مكتبة الثقافة بالمدينة المنورة .

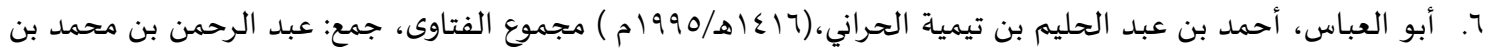

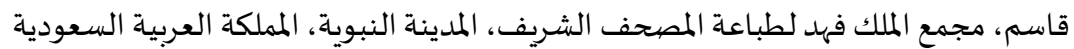

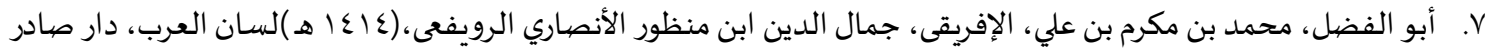
- بيروت، الطبعة الثالثة A. أبو زيد، بكر بن عبد الله،(VI\& هـ -1997 م ) معجم المناهي اللفظية وفوائد في الألفاظ، دار العاصيمة للنشر والتوزيع الرياض، الطبعة الثالثة

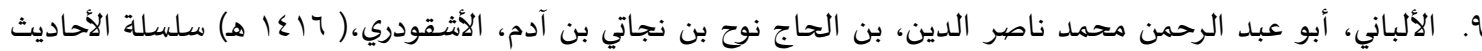
الصحيحة وشيء من فقهها وفوائدها)، مكتبة المعارف للنشر والتوزيع، الرياض، الطبعة: الأولى.

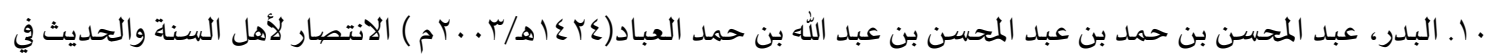
رد أباطيل حسن المالكي، دار الفضيلة، الرياض، المملكة العربية السعودية، الطبعة: الأولى.

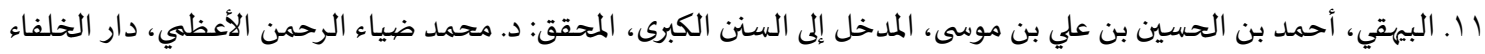

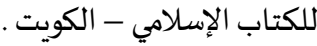

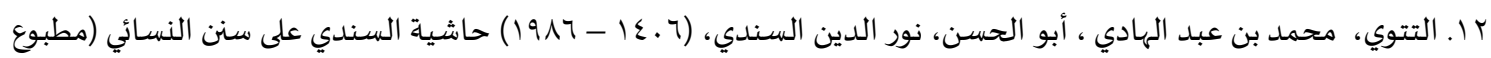
مع السنن)، الناشر: مكتب المطبوعات الإسلامية - حلب، الطبعة الثانية

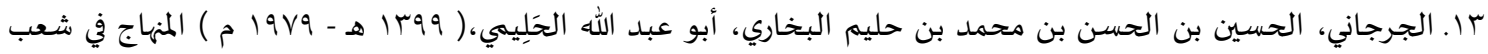

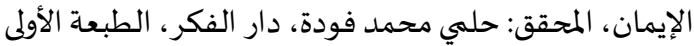

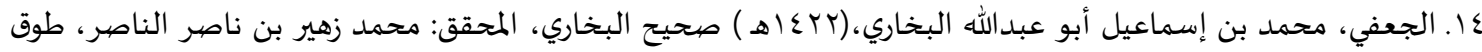

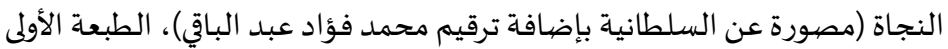

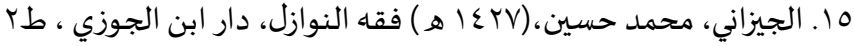




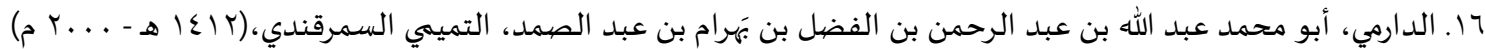
مسند الدارمي المعروف بـ(سنن الدارمي)، تحقيق: حسين سليم أسد الداراني، المغني للنشر والتوزيع، المملكة العربية السعودية، الطبعة الأولى.

V الدمشقي، تقي الدين أبو العباس أحمد بن عبد الحليم بن عبد السلام بن عبد الله بن أبي القاسم بن محمد ابن تيمية الحراني

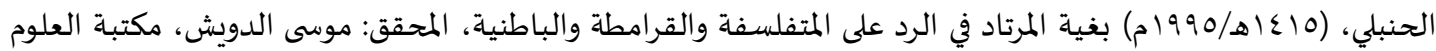
والحكم، المدينة المنورة، المملكة العربية السعودية الطبعة الثالثة.

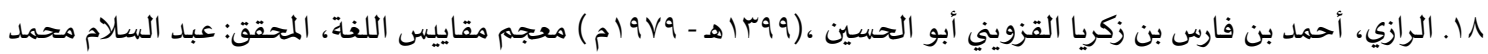
هارون، دار الفكر.

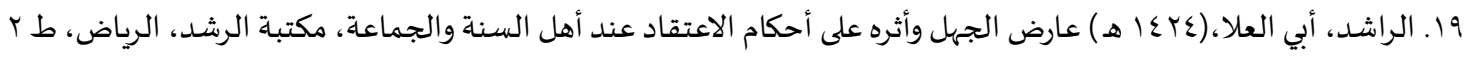

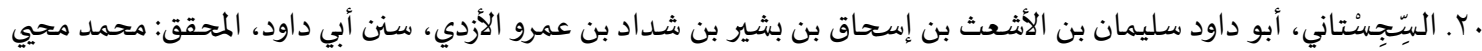

الدين عبد الحميد، المكتبة العصبرية، صيدا - بيروت .

آr. الشافعي، أحمد بن علي بن حجر أبو الفضل العسقلاني،(rVq اهـ) فتح الباري شرح صحيح البخاري، رقم كتبه وأبوابه

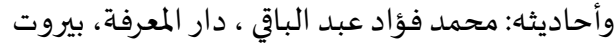

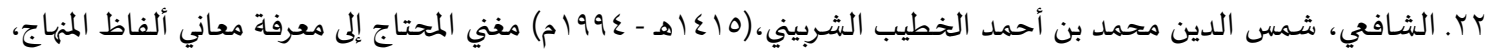
دار الكتب العلمية، الطبعة الأولى

بr. الشافعي، محمد بن إدريس، الرسالة ، تحقيق : أحمد شاكر ، دار الحار الكتب العلمية.

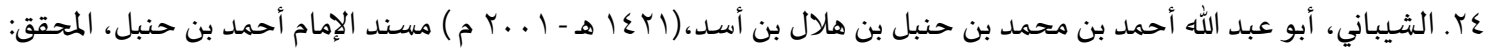

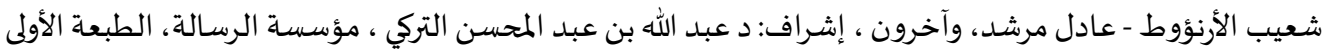

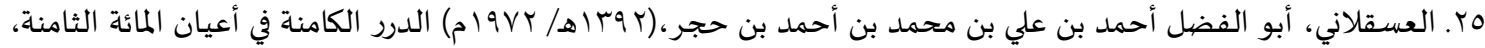

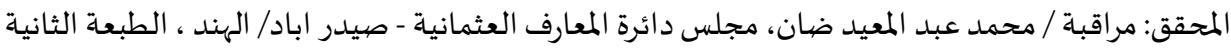

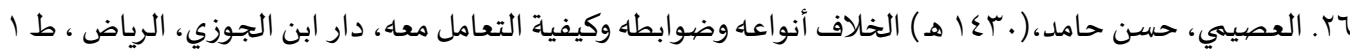

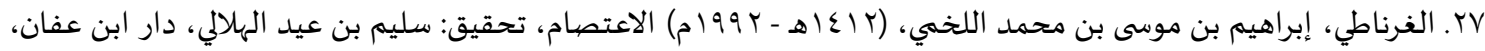
السعودياة، الطبعة الأولى

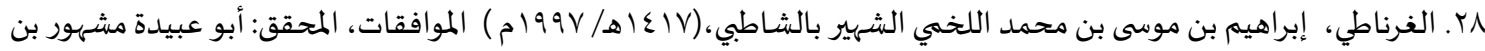

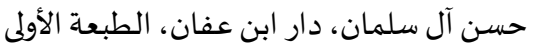

وr. الفيومي، أحمد بن محمد بن علي ثم الحموي، أبو العباس،( (19 أهـ ) المطالب العالية بزوائد المسانيد الثمانية ، أبو الفضل

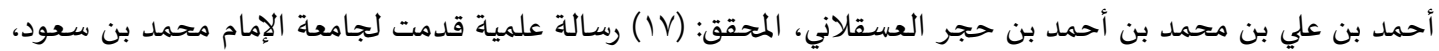

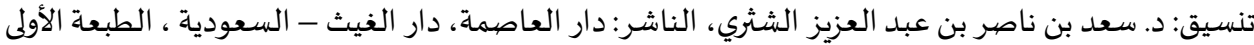

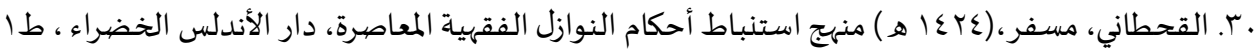

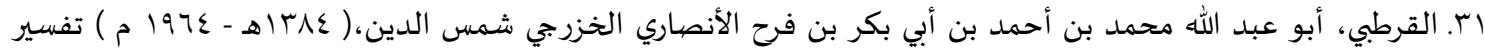

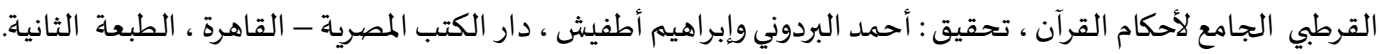

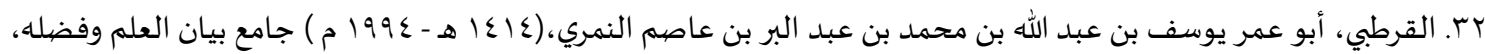

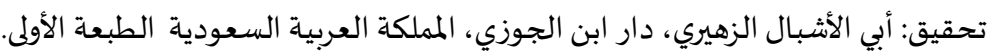

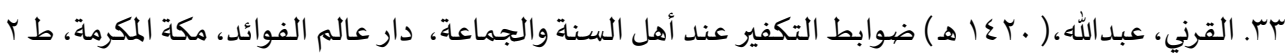

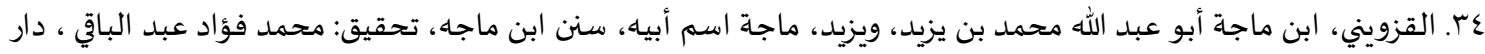

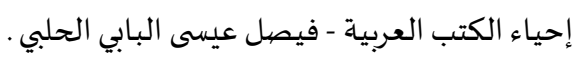

0r. المصباح المنير في غريب الشرح الكبير ، (المتوفى: نحو · .Vه) ، المكتبة العلمية - بيروت .

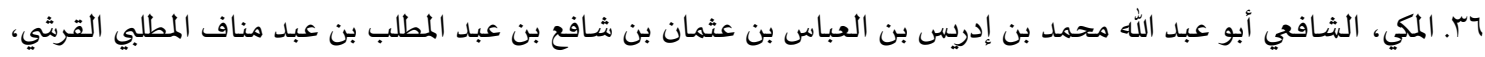

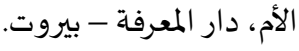

V V. المعجم الوسيط، مجمع اللغة العربية بالقاهرة، تحقيق (إبراهيم مصطفى / أحمد الزيات / حامد عبد القادر / محمد النجار)، دار الدعوة. 
مب. الموسوعة الميسرة في الأديان والمذاهب والأحزاب المعاصرة، الندوة العالمية للشباب الإسلامي، إشراف وتخطيط ومراجعة: د. مانع

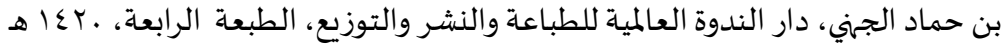

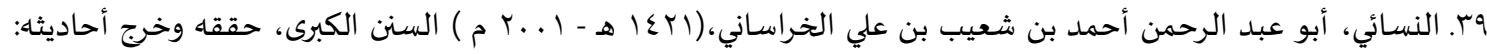
حسن عبد المنعم شلبي ، مؤسسة الرسالة - بيروت، الطبعة الأولى

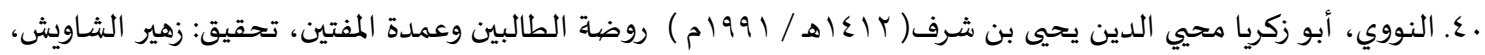
المكتب الإسلامي، بيروت- دمشق- عمان ، الطبعة الثالثة

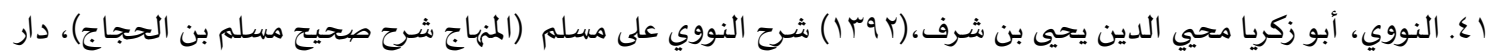
إحياء التراث العربي - بيروت، الطبعة الثانية

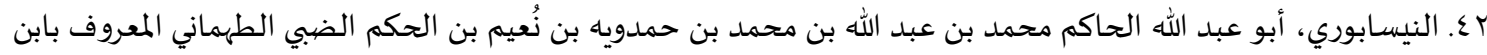

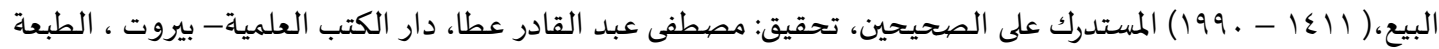
الأولى

بع. النيسابوري، مسلم بن الحجاج أبو الحسن القشيري، صحيح مسلم، المحقق: محمد فؤاد عبد الباقي، دار إحياء التراث العربي - بيروت .

عـ. الوهيبي، محمد، (7 ع 1 هـ) نواقض الإيمان الاعتقادية وضوابط التكفير عند السلف، دار المسلم ، الرياض، ط الماض

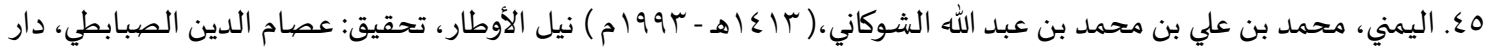

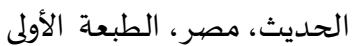
7ع. اليمني، محمد بن علي بن محمد بن عبد الله الشوكاني، البدر الطالع بمحاسن من بعد القرن السـابع، الناشر: دار المعرفة بيروت.

V V. بن أبي عاصهم، أبي بكر عمر،(. . ع اهـ) السنة تحقيق: محمد ناصر الدين الألباني، المكتب الإسلامي، طا.

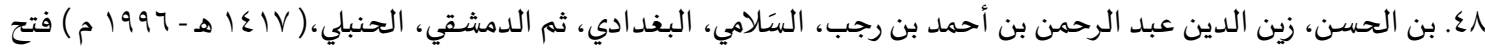

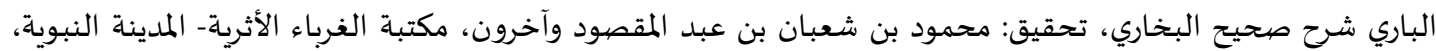

الطبعة الأولى الطباح

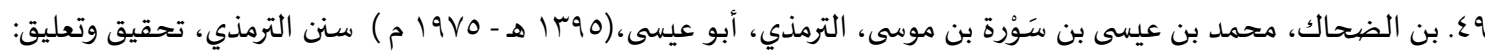

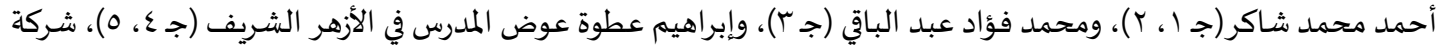
مكتبة ومطبعة مصطفى البابي الحلبي - مصري، الطبعة الثانية

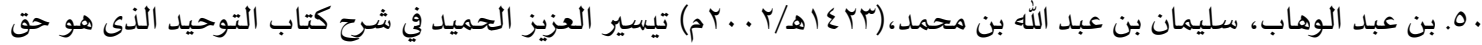

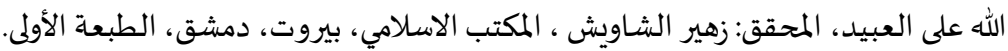

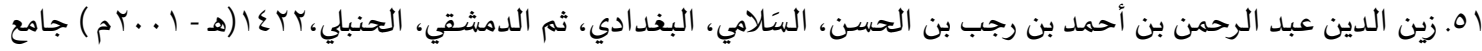
العلوم والحكم في شرح خمسين حديثا من جوامع الكلم، المحقق: شعيب الأرناؤوط - إبراهيم باجس، مؤسسة الرسالة - بيروت ، مهبعة السـابعة

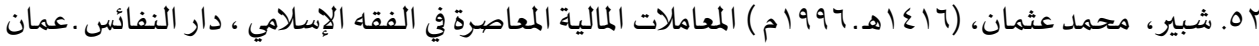

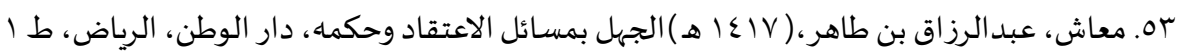


Refaad

رفاد للدراسات والأبحاث

www.refaad.com
المجلة الدولية للدراسات الإسلامية المتخصصية

e-ISSN 2617-6246, p-ISSN 2617-6238

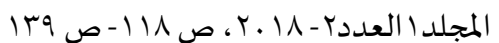

https://doi.org/DOI:10.31559/sis2018.1.2.1

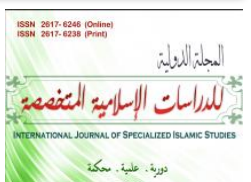

\title{
The Contractual Insults of New Musilms
}

\author{
Zeyad Hamad Alamer \\ Associate Professor of Contemporary Ideology and Ideology- University Almujmaea \\ Zha1430@gmail.com
}

\begin{abstract}
With the passage of time, people have suffered from insults that were not in their ancestors, an interaction of the turnout when entering the religion of Islam, especially in countries where sovereignty or pluralism is not for the people of Islam, and the spread of ignorance and the large number of non-Muslims, which made many knowledge of Islam melt in the hearts of Muslims The people of these countries, and supported the stability of those who know the customs, permitting the owners of the new decade in the ranks of new Muslims in that country, this research was an attempt to participate in resolving some of the new Muslim's objection.
\end{abstract}

Keywords: Insults, Doctrine, Muslim, New

\section{References:}

- Ạlqrận Ạlkrym.

[1] Abrạhym. Mḥmd Ysry, Fqh Ạlnwạzl Llạ̉qlyạt Ạlmslmh Tạ̉ṣylạaa ${ }^{\mathrm{n}}$ Wtṭbyqạan ${ }^{\mathrm{n}}$, Dạr Ạlysr, Jmhwrÿ̈ Mșr, T 2, (1433h)

[2] Ạbn Ạlặthyr. Ạ̉by Ạls ạdạt Ạlmbạrk Bn Mḥmd Ạljzry, Ạlnhạyh Fy Gh̄ryb Ạlḥdythِ

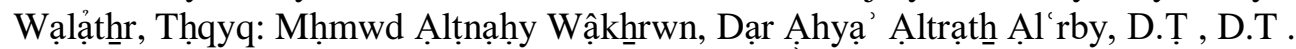

[3] Ạbn Qym Ạljwzyh. Mḥmd Bn Ạ̉by Bkr Bn Ảywb Bn S'd Sḥms Ạldyn, A 'lạm Ạlmwq yn 'n Rb Ạl'ạlmyn, Tḥqyq: Mḥmd 'bd Ạlslạm ẠBrạhym, Dạr Ạlktb Ạl'lmyh - Byrwt, Ạlțb h Ạlạ̉wla, (1411h- 1991m)

[4] Ạbn Qym Ạljwzyh. Mḥmd Bn Ạ̉by Bkr Bn Ạ̉ywb Bn S'd Sḥms Ạldyn, Ạlṣlạh Wạ̉hkạm Tạrkhạ, Mktbë Ạlthquạfh Bạlmdynh Ạlmnwrh .

[5] Ạ̉bw Al' bạs. Ạhmọn Bn 'bd Ạlḥlym Bn Tymyë Ạlhrạny, Mjmw' Ạlftạwy, Jm': 'bd Ạlrḥmn Bn Mḥmd Bn Qạsm, Mjm Ạlmlk Fhd Lṭbạ'h Ạlmṣḥ Ạlsḥryf, Ậlmdynh Ạlnbwyh, Ạlmmlkh Ạl'rbyh Ạls`wdyh, (1416h/1995m)

[6] Ạ̉bw Ạlfụl. Mḥmd Bn Mkrm Bn 'ly, AlạFryqy \& Jmạl Ạldyn Ạbn Mnẓwr Ạlạ̉nṣạry Ạlrwyf 'ý, Lsạn Ạl'rb, Dạr Ṣạdr- Byrwt, Ạlțb'h Ạltḥạlthhh, (1414h )

[7] Ạ̉bw Zyd. Bkr Bn 'bd Ạllh, M'jm Ạlmnạhy Ạllfẓyh Wfwậ̉d Fy Ạlạ̉lfạz, Dạr Ạl lạṣmh

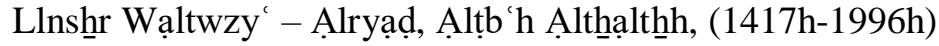

[8] Ậl 'bd Ạllțyf. 'bd Ạl'zyz , Nwạqḍ Ạlại Ymạn Ạlqwlyh Wạl'mlyh, Dạr Ạlwṭn, Ạlryạ̣̣, T 2,(1415 h) 
[9] Ạl'sqlạny. Ạ̉bw Ạlfạl Ạ̉hmmd Bn 'ly Bn Mḥmd Bn Ạ̉hmm Bn Ḥjr, Ạldrr Ạlkạmnh Fy Ạ̉ yạn Ạlmạyhh Ạlthạmnh, Ạlmḥqq: Mrạqbh / Mḥmd 'bd A.lm yd Dạn, Mjls Dạyrr̈ Ạlm'ạrf Ạl tḥmạnyh - Șydr Ạbạd/ Ạlhnd, Altṭb 'hẠlthạnyh, (1392h-1972m)

[10] All'ṣymy, Ḥsn Hạmd, Ạlkḥlạf Ạ̉nwậh Wḍwạbṭh Wkyfyh Ạlt'ạml M'h, Dạr Ạbn Ạljwzy, Ạlryạḍ, Ṭ1,(1430h)

[11] Alạ̉lbạny. Ạ̉bw 'bd Ạlrḥmn Mḥmd Nạșr Alldyn, Bn Ạlhạj Nwḥ Bn Njạty Bn Ậdm,

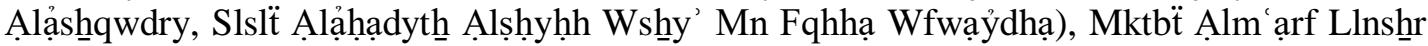
Wạltwzy', Ạlryạḍ, Alț̣ 'h Ạlạ̉wla, (1416h)

[12] Ạlbdr. 'bd Ạlmḥsn Bn Ḥmd Bn 'bd Ạlmḥsn Bn 'bd Ạllh Bn Ḥmd Ạl'bạd, Ạlạntșạr Lạ̉hl Ạlsnh Wạlḥdyth Fy Rd Ạ̉bạtyl Husn Ạlmạlky, Dạr Ạlfḍlhl Ạlryạ̣, Ạlmmlkh Ạl'rbyh Ạls 'wdyh, Ạlṭb'h Ạlạ̉wla, (1424h/2003m)

[13] Ạlbyhqy. Ạhmmd Bn Ạlḥsyn Bn 'ly Bn Mwsy, Ạlmdkḥl ẠLy Ạlsnn Ạlkbry, Ạlmḥqq: D. Mḥmd Ḍyạ’ Ạlrḥmn Ạlạ̉ zọmy, Dạr Ạlkhllfạ’ Llktạb Ạlạ̣slạmy - Ạlkwyt .

[14] Ạldạrmy. Ạ̉bw Mḥmd 'bd Ạllh Bn 'bd Ạlrḥmn Bn Ạlfụl Bn Bahrạm Bn 'bd Ạlṣmd, Ạltmymy Ạlsmrqndy, Msnd Ạldạrmy Ạlm rwo B(Snn Ạldạrmy), Thquq: Ḥsyn Slym Ạ̉sd Ạldạrạny, Ạlmghnny Llnsḥr Wạltwzy', Ạlmmlkh Ạl'rbyh Ạls'wdyh, Ạlțb hh Ạlạ̉wla, (1412h$2000 \mathrm{~m})$

[15] Aldmshạy. Tqy Ạldyn Ạ̉bw Al bạs Ạ̉hmd Bn 'bd Ạlḥlym Bn 'bd Ạlslạm Bn 'bd Ạllh Bn Ạ̉by Ạlqạsm Bn Mḥmd Ạbn Tymyh Ạlḥ̣ạny Ạlḥnbly, Bghbyh Ạlmrtạd Fy Ạlrd 'ly A.lmtflsfh Wạlqrạmțh Wạlbạtnyh, Ạlmḥqq: Mwsy Ạldwysh̆, Mktb̈̈ Ạl'lwm Wạlḥkm, Ạlmdynh Ạlmnwrh, Ạlmmlkh Ạl'rbyh Ạls 'wdyh Ậlțb h Ạlthạlth, (1415h/1995m)

[16] Alfywmy. Ạhmo Bn Mhmd Bn 'ly Tḥm Ạlhmwy, Ạ̉bw Ạl'bạs, Almțạlb Ạl'ạlyh Bzwạyd Ạlmsạnyd Ạltḥmạnyh, Ạ̉bw Ạlfụl Ạ̉hmo Bn 'ly Bn Mḥmd Bn Ạ̉ḥmd Bn Hjr Ạl'sqlạny, Almḥqq: (17) Rsạlh 'lmyh Qdmt Ljạm ‘̈ AlạMạm Mḥmd Bn S'wd, Tnsyq: D. S'd Bn Nạṣr

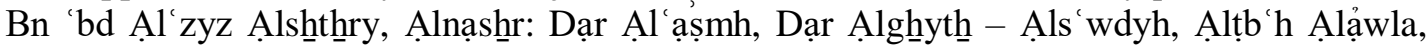
$(1419 h)$

[17] Ạlgḥrnạty. Ạbrạhym Bn Mwsy Bn Mḥmd Ạllkhmmy, Ạlạ tșạm, Tḥqyq: Slym Bn 'yd Ạlhlạly, Dạr Ạbn 'fạn, Ạls 'wdyh, Alțb ho Alạ̉wla, (1412h-1992m)

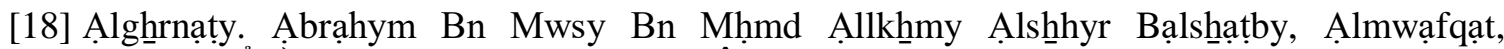
Ạlmḥqq: Ạ̉bw 'bydh Msḥhwr Bn Hisn Ậl Slmạn, Dạr Ạbn 'fạn, Ạlṭb'h Ạlạ̉wla, (1417h$1997 \mathrm{~m})$

[19] Alj fy, Mḥmd Bn Ạ̦Smạ yl Ạ̉bw 'bdạllh Albkhạry, Șḥyḥ Ạlbkhạary, Ạlmḥqq: Mḥmd Zhyr Bn Nạṣr Ạlnạșr, Ṭwq Ạlnjạh (Mṣwrh 'n Ạlslțanyh Bạdạft Trqym Mḥmd Fwạa 'bd Ạlbạqy), Ạlṭb h Ạlạ̉wlya,(1422h)

[20] Ạljrjạny. Ạlḥsyn Bn Ạlḥsn Bn Mḥmd Bn Ḥlym Ạlbkhạry, Ạ̉bw 'bd Ạllh Ạlḥalīmy, Ạlmnhạj

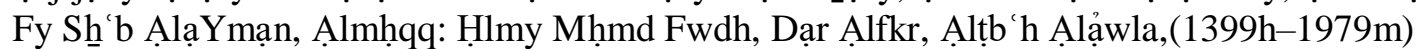

[21] Ạljyzạny. Mḥmd Ḥsyn, Fqh Ạlnwạzl, Dạr Ạbn Ạljwzy, Ṭ2, (1427h)

[22] Alqhṭạny, Msfr, Mnhj Ạstnbạt Ạhḳạm Ạlnwạzl Ạlfqhyh Ạlm 'ạșrh, Dạr Ạlạ̉ndls Ạlkhụdrạ’, Ț1, (1424h) 
[23] Ạlqrṭby. Ạ̉bw 'bd Ạllh Mḥmd Bn Ạ̉ḥmd Bn Ạ̉by Bkr Bn Frḥ Ạlạ̉nṣạry Ạlkḥzrjy Shms Ạldyn Tfsyr Ạlqrṭby Aljạm ' Lạ̉hkạm Ạlqrận, Tḥqyq: Ạhmd Ạlbrdwny WạiBrạhym Ạtteysh , Dạr Ạlktb Ạlmșryh- Ạlqạhrh, Ạlțb ‘h Ạlthạnyh,(1384h-1964m)

[24] Ạlqrṭby. Ạ̉bw 'mr Ywsf Bn 'bd Ạllh Bn Mḥmd Bn 'bd Ạlbr Bn 'ạṣm Ạlnmry, Jạm' Byạn Ạl'lm Wfạlh, Thquq: Ạ̉by Alạ̉sḥbạl Ạlzhyry, Dạr Ạbn Ạljwzy, Ạlmmlkh Ạl'rbyh Ạls 'wdyh, Alțb'h Ạlạ̉wla,(1414h-1994m)

[25] Ạlqrny, 'bdạllh, Dwạabt Ạltkfyr 'nd Ạ̉hl Ạlsnh Wạljmạ'h, Dạr 'ạlm Ạlfwạỷd, Mkh Ạlmkrmh, Ț2, (1420h)

[26] Ạlqzwyny. Ạbn Mạjh Ạ̉bw 'bd Ạllh Mḥmd Bn Yzyd, Wyzyd, Mạjh Ạsm Ạ̉byh, Snn Ạbn Mạjh, Tḥqyq: Mḥmd Fwạad 'bd Ạlbạqy, Dạr Ạ̧Hyạ' Ạlktb Ạl'rbyh - Fyṣl 'ysy Ạlbạby Ạlḥlby.

[27] Ạlm jm Ạlwsyț, Mjm Ạllghh Ạl'rbyh Bạlqạhrh, Tḥqyq (ẠBrạhym Mșțy/ Ạ̉ḥmd Ạlzyạt / Hạmd 'bd Ạlqạdr/ Mḥmd Ạlnjạr), Dạr Ạld'wh.

[28] Ạlmky. Ạlshạf'y Ạ̉bw 'bd Ạllh Mḥmd Bn ẠDrys Bn Ạl'bạs Bn 'tḥmạn Bn Shạaf' Bn 'bd Ạlmṭlb Bn ‘bd Mnạf Ạlmṭlby Ạlqrshy, Ạlạ̉m, Dạr Ạlm rrfh - Byrwt.

[29] Ạlmṣbạh Ạlmnyr Fy Ghryb Ậlsḥrḥ Ạlkbyr, Ạlmktbh Ạl’ lmyh- Byrwt.

[30] Ạlmwsw'h Ạlmysrh Fy Ạlạ̉dyạn Wạlmdhạhb Wạlạhhạạ Ạlm'ạṣrh, Ạlndwh Ạl'ạlmyh Llsḩbạb Alạslạmy, AShrrạf Wtkḥtyt Wmrạj h: D. Mạn Bn Ḥạd Ạljhny, Dạr Ạlndwh

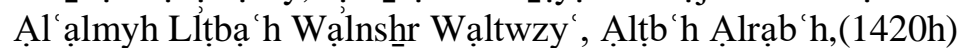

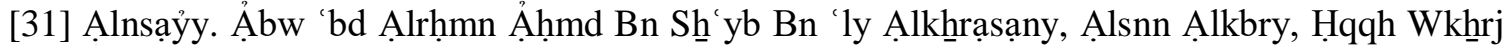

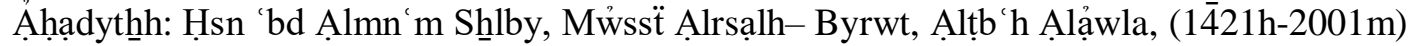

[32] Ạlnwwy. Ạ̉bw Zkryạ Mḥyy Ạldyn Yḥyy Bn Sh̆rf, Rwḍ̈t Ạltạlbyn W'md̈̈ Ạlmftyn, Tḥqyq: Zhyr Ạlshạwysh̆, Ạlmktb ẠlạiSlạmy, Byrwt- Dmshq- 'mạn , Ạlțb'h Ạlthạaltḥh, (1412h$1991 \mathrm{~m}$ )

[33] Ạlnwwy. Ạ̉bw Zkryạ Mḥyy Ạldyn Yḥyy Bn Sh̆rf, Shrḥ̣ Ạlnwwy 'ly Mslm (Ạlmnhạj Sh̆rḥ

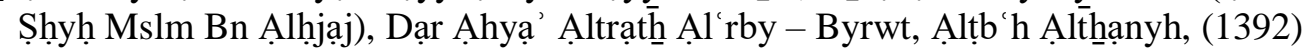

[34] Ạlnysạbwry. Ạ̉bw 'bd Ạllh Ạlhạkm Mḥmd Bn 'bd Ạllh Bn Mḥmd Bn Họdwyh Bn Nu ym Bn Alḷkm Ạlḍby Ạlțhmạny Ạlm'rwf Bạbn A.lby', Almstdrk 'ly Alṣ̣hyḥyn, Tḥqyq: Mṣțy 'bd Ạlqạdr 'țạ, Dạr Ạlktb Ạl'lmyh- Byrwt, Ạlṭb'h Ạlạ̉wla, (1411-1990)

[35] Ạlnysạbwry. Mslm Bn Ạlḥjạj Ạ̉bw Ạlḥsn Ạlqshhyry, Șhỵh Mslm, Ạlmḥqq: Mḥmd Fwạạd 'bd Ạlbạqy, Dạr A̧Hyạ’ Ạltrạth A. Al rby - Byrwt .

[36] Ạlrạshnd. Ạ̉by Ạl'lạ, 'ạrḍ Ạljhl Wạ̉thַrh 'ly Ạ̉hkạm Ạlạ tqạd 'nd Ạ̉hl Ạlsnh Wạljmạ ho, Mktbë Ạlrshd, Ạlryạd, Ț2, (1424h)

[37] Ạlrạzy. Ạhmo Bn Fạrs Bn Zkryạ Ạlqzwyny Ạ̉bw Ạlḥsyn , M’jm Mqạyys Ạllghhh, Ạlmḥqq: 'bd Ạlslạm Mḥmd Hạrwn, Dạr Ạlfkr, (1399h- 1979m)

[38] Ạlshyybạny. Ạ̉bw 'bd Ạllh Ạ̉hmmd Bn Mḥmd Bn Ḥnbl Bn Hlạl Bn Ạ̉sd, Msnd Ạlạiạm Ạ̉ḥmd

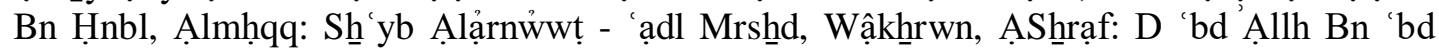
Ạlmḥsn Ạltrky, Mw̉ssẗ Ạlrsạlh, Ạlṭb h Ạlạ̉wla, (1421h-2001m) 
[39] Ạlshạf'y. Ạ̉hmmd Bn 'ly Bn Ḥjr Ạ̉bw Ạlfụl Ạl'sqlạny, Ftḥ Ạlbạry Sḥrḥ Șḥyḥ Ạlbkḥạry, Rqm Ktbh Wạ̉bwạbh Wạ̉hạdythhh: Mḥmd Fwạad 'bd Ạlbạqy, Dạr Ạlm'rfh, Byrwt, (1379h)

[40] Ạlshạf'y. Mḥmd Bn Ạdrys, Ạlrsạlh, Tḥqyq: Ạ̉hmd Sḥạkr, Dạr Ạlktb Ạl'lmyh.

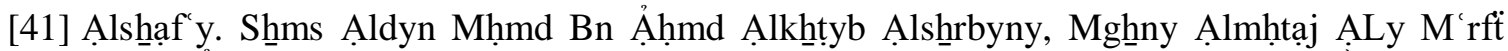
M’ạny Ạllfạz Ạlmnhạj, Dạr Ạlktb Ạl lmyh, Ạlțb h Ạlạ̉wla, (1415h-1994m)

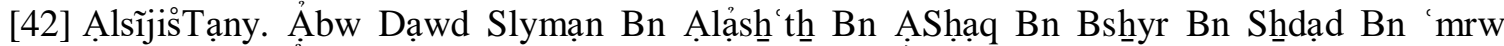
Ạlạ̉zdy, Snn Ạ̉by Dạwd, Ạlmḥqq: Mḥmd Mḥyy Ạldyn 'bd Ạlḥmyd, Ạlmktbĕ Ạl'ṣryh, Șydạ - Byrwt .

[43] Alttwy. Mḥmd Bn 'bd Ạlhạdy , Ạ̉bw Ạlḥsn, Nwr Ạldyn Ạlsndy, Hạshyÿ Ạlsndy 'ly Snn

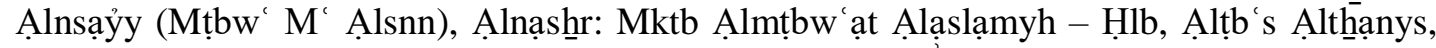
(1406-1986)

[44] Ạlwhyby. Mḥmd, Nwạqḍ Ạlạymạn Ạlạ tqạdyh Wḍ̂ạbṭ Ạltkfyr 'nd Ạlslf, Dạr Ạlmslm, Ạlryạ̣, Ṭ1,(1416h)

[45] Allymny. Mḥmd Bn 'ly Bn Mḥmd Bn 'bd Ậllh Ạlsḥwkạny, Ạlbdr Ậlțạl Bmḥạsn Mn B'd Ạlqrn Ạlsạb', Ạlnạshnr: Dạr Ạlm rofh- Byrwt.

[46] Alymny. Mḥmd Bn 'ly Bn Mḥmd Bn 'bd Allh Ạlsḥwkạny, Nyl Ạlạ̉wțạr, Tḥqyq: 'ṣạm Ậldyn Ạlṣ̣bạbțy, Dạr Ạlḥ̣dyth̆, Mṣr, Ạlțb h Ạlạ̉wly, (1413h-1993m)

[47] Bn 'bd Ạlwhạb. Slymạn Bn 'bd Ạllh Bn Mḥmd, Tysyr Al'zyz Ạlhmyd Fy Sḥrḥ Ktạb Ạltwhyd Ạldhy Hw Ha Ạllh 'ly Ạl'byd, Ạlmḥqq: Zhyr Ạlshạwysh , Ạlmktb Ạlạslạmy, Byrwt, Dmshqu, Ạlțb h Ạlạ̉wla, (1423h-2002m)

[48] Bn Ạ̉by 'ạsm. Ạ̉by Bkr 'mr, Ạlsnh Tḥqyq: Mḥmd Nạṣ Ạldyn Ạlạ̉lbạny, Ạlmktb Ạlạslạmy,Ṭ1, (1400h)

[49] Bn Ạlḍhạk. Mḥmd Bn 'ysy Bn Saworh Bn Mwsa, Ạltrmdhyy, Ạ̉bw 'ysy, Snn Ạltrmdhy, Tḥqyq Wt'lyq: Ạ̉hmd Mḥmd Shạkr(J 1, 2), Wmḥmd Fwạad 'bd Ạlbạqy (J 3), WạBrạhym

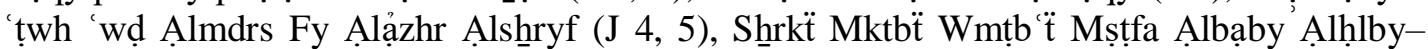
Mṣr, Alț̣ h Althạnyh, (1395h-1975m)

[50] Bn Ạlḥsn. Zyn Ạldyn 'bd Ạlrḥmn Bn Ạhḥmd Bn Rjb, Ạlsalạmy, Ạlbghndạdy, Tḥm Ạldmshnqy, Ạlḥnbly, Ftḥ Ạlbạry Sḥrḥ Șhyḥ Ạlbkhạry, Tḥqyq: Mḥmwd Bn Sḥ bạn Bn 'bd Ạlmqșwd

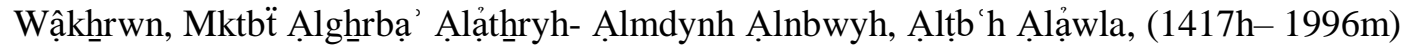

[51] M'ạsh̆, 'bdạlrzạq Bn Ṭạhr, Ạljhl Bmsạỷ Ạlạ tqạad Wḥkmh, Dạr Ạlwṭn, Ạlryạạ, Ṭ1,(1417h)

[52] Shbbyr. Mḥmd 'tḥmạn, Ạlm ạmlạt Ạlmạlyh Ạlm ạ̣ṣh Fy Ạlfquh Ạlạislạmy, Dạr Ạlnfạỷs 'mạn, (1416h-1996m)

[53] Zyn Ạldyn 'bd Ạlrḥmn Bn Ạ̉ḥmd Bn Rjb Bn Ạlḥsn, Ạlsalạmy, Ạlbgḥdạdy, Tḥm Ạldmshnqy,

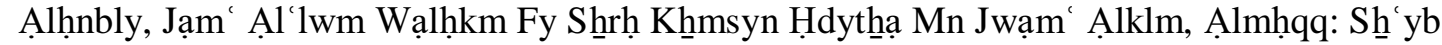
Ạlạ̉rnạwwț- ẠBrạhym Bạjs, Mw̉ssẗ Ạlrsạlh- Byrwt , Altṭb h Ạlsạb ho,(1422h- 2001m) 